\title{
THE ECUMENICAL MOVEMENT IN INDONESIA WITH SPECIAL ATTENTION TO THE NATIONAL COUNCIL OF CHURCHES
}

The parameter or indicator commonly used to monitor the process of the ecumenical movement in Indonesia is the National Council of Churches, the Dewan Gereja-gereja di Indonesia (DGI, founded in 1950 and since 1984 the Persekutuan Gereja-gereja di Indonesia, PGI). DGI/PGI, however, is not identical with the ecumenical movement. The performance of this institution, especially during the last ten years, might even be contrary to the spirit of the movement, as observed with a deep concern by many church leaders and ministers. ${ }^{1}$ Besides that, as we will see, there are some other councils or communions of churches in Indonesia that also claim to be ecumenical institutions.

However, DGI/PGI plays a very strong and significant role. It is commonly recognised as a 'flag-carrier' of the ecumenical movement in this country and-at least until the 1980s-the representative of the Protestant Churches with both the government and the other faiths. Therefore we will pay particular attention to it, while also taking into account the seeds and the development of the ecumenical movement quite a long time before its foundation as well as the role of some other institutions or groups that also claim to be the expression and the manifestation of this movement and spirit. By doing this we also see the various and wide understanding of ecumene among the churches and Christians in this country.

The development of the ecumenical movement in this country is part of an international movement, including a variety of ecumenical understanding and expression. Therefore we cannot avoid glimpsing aspects of the global history, especially among the mission organisations and conferences that initiated this movement. As this movement is also influenced by political and ideological reality (like the emergence of nationalism among the colonized countries since the beginning of the twentieth century), we also have to note this history in global as well as in national perspective. In line with this, the three-self idea and movement (self-supporting, self-propagating and self-government) also made a mutual contribution to the ecumenical movement, in that they foster each other's growth.

\footnotetext{
${ }^{1}$ As expressed by Joas Adiprasetya, a young minister and theologian, doing his Ph.D. at Boston College, USA, in his paper "Inisiatif Kaum Muda dalam Gerakan Ekumene: Tantangan dan Terobosan," (Young generation initiatives in the ecumenical movement: challenge and break-through), 9 November 2001.
} 
As a general survey, this chapter will mainly rely upon formal and institutional publications, but in certain cases it also tries to give a real portrait of developments in the field. The scope of the ecumenical movement will be too diminished if it is only seen in its formal activities or formulations. Therefore the burning issues will also be presented to see the dynamic of this movement.

\section{The Seeds and Pioneers ${ }^{2}$}

As already mentioned in chapter six, in the first half of the nineteenth century the king of the Netherlands and the Dutch colonial government initiated a new church institution in this country that was called the Protestant Church in the Dutch East Indies, commonly called the Indische Kerk. From the confessional perspective this church had a quite serious weakness: it had no confessional identity. But from a certain point of view we can also say that this church united the Reformed, Lutheran and other Protestant traditions and it did not emphasize doctrinal uniformity, so that to a certain extent this church could also be referred as one of the pioneers of the ecumenical spirit.

Meanwhile, from the beginning of the nineteenth century more and more missionary societies chose this country as their mission field. Already from the second half of the nineteenth century onwards a consciousness grew among these missionary societies that they should build cooperation in various sectors. First cooperation was in the media of information and communication (cf. chapter twenty-one). From 1851 onwards they published a monthly called Opwekker (Awakener). In the beginning this bulletin was initiated by a missionary society, the Genootschap voor In- en Uitwendige Zending (Society for Internal and External Mission) led by Rev. E.W. King, and from 1881 until 1941 it was taken over and published by a newly founded association of missionaries from various mission bodies, the Nederlandsch Indische Zendingsbond (NIZB). This bulletin contained reports of the various missionary conferences and gave wide room for articles that stimulated discussions regarding the development of mission and churches, including cooperation and unity among them.

A second field of cooperation was the preparation of indigenous workers. In 1869 J.A. Schuurman, a minister in Batavia/Jakarta, published an article to summon Christians in this country to build a seminary. This appeal was responded to positively by some missionary societies, and in 1878 they built the seminary in Depok, around $35 \mathrm{~km}$ south of Batavia. Many mission societies

2 This section is mainly based on Hartono 1984:9-57; Holtrop 1982:7-22; Ngelow 1982:3-30 and 1994:107-174; Ukur, "Tinjauan Sejarah," in: Aritonang (ed.) 2000:12-17; Van den End ${ }^{5}$ 2002:381-385; and Hoekema 1997:96-229. 
sent students from their mission fields: Batakland, Minahasa, Timor, SangirTalaud, as well as from the fields in Java. Through the process of learning and teaching among the teachers and the students they were enriched and learned many valuable things from each other, and developed a spirit of cooperation and unity that was later called the ecumenical spirit. This spirit was expressed in many ways when the students finished their study and went back to their own churches.

This Depok Seminary was closed in 1926 because the sponsoring societies had opened their respective seminaries and planned to start a higher or university level seminary. This plan was implemented in the founding of the so-called Hoogere Theologische School (Higher School of Theology) in 1934 (since 1936 moved to Batavia/Jakarta, and since 1954 known as the Sekolah Tinggi Theologia [STT] Jakarta). The role of this theological school in the development of the ecumenical spirit and movement is very remarkable, up to the present. Dr. Hendrik Kraemer, one of the initiators of this school, said in his inaugural speech that in the future the existence and role of this school would be theologically and ecclesiastically very important for the development of a strong and undivided Indonesian Protestant Christian community, even though the churches are separated by geographical and ethnic factors.

A third step towards cooperation was the forming of the above-mentioned union of mission societies, NIZB, in 1881, as an agreement and decision of a missionary conference at Depok Seminary in 1880 . NIZB regularly organised missionary conferences to discuss actual issues and problems dealing with mission and evangelism. From the 1920s NIZB also discussed the development of the churches towards autonomy and self-subsistence as well as the cooperation and unity of the churches. From 1928 until 1941 NIZB even planned the founding of a council of missionary societies and churches that would function as, and should be upgraded to be, a national Christian council. Due to some obstacles, up to the last conference of the NIZB in Karang Pandan in 1941, this idea could not be implemented, although the preparatory committee had already prepared a draft of its constitution. However, this conference is very important because it was also attended by some prominent indigenous leaders like Soewidji, J. Leimena and Amir Sjarifuddin, who proposed their ideas regarding the unity of the churches in Indonesia as well as the standpoint and the role of the churches in the nationalist movement. They also criticized the missionary societies who did not build and support political consciousness and the spirit of nationalism among the indigenous Christians.

A fourth step was the founding of the Zendingsconsulaat (Mission Consulate, 1906) as a connecting link between the government and the boards of the various missionary societies in this country. The harmonious relationship between the colonial government and the mission consulate in Batavia enhanced the daily intercourse of missionaries and civil servants. It also influenced the 
cooperation of the missionary societies in the Netherlands, including the founding of the Dutch Missionary Council in 1929. This consulate existed until 1953 and played a significant role in fostering the cooperation and growth of the churches through their respective missionary societies. ${ }^{3}$

The role of the Bible Society is also worthy of mention. As an interchurch and intermission institution, the Nederlands Bijbelgenootschap (NBG) was designated as the parent organization for the Mission Consulate. More important was the NBG's role (and in a much lesser degree that of the British and Foreign Bible Society) in providing infrastructure and qualified personnel for the translation of the Bible in a number of Indonesian languages, and especially in looking for a solution to the difficult problem of selecting one out of the many varieties of Malay to become the language of a common Malay Bible that could take the place of the Leijdecker and, in the twentieth century, the Klinkert translation. However, this problem was only solved after the Lembaga Alkitab Indonesia (LAI, Indonesian Bible Society) had taken over the lead in this field from the NBG (1954).

Among the Chinese churches, especially in Java, there was a development worthy to note. The spirit of unity among these churches had a close connection with the nationalist movement led by Sun Yat Sen, and the ecumenical movement in China as seen among other things in the founding of NCC in China in 1922. The first step was taken in their conference in Bogor in November 1926, led by Rev. Pouw Peng Hong. This conference agreed to form a forum for the Chinese Christians that they called the Bond van Chinese Christenen in Indonesië, with a goal to unite all Chinese Christians in Indonesia. In spite of some weaknesses, such as having a more Chinese than Indonesian character, they continued to develop by forming a new institution they called the Geredja Tionghoa Serikat (Chinese United Church). However, until the 1940s, the idea of uniting all Chinese churches in one institution was still a dream; they could only form, in 1948, a council for the Chinese churches that they called the Dewan Geredja-geredja Kristen Tionghoa. ${ }^{4}$

We also have to mention the founding of students' and women's organisations. In 1924 the Nederlandsche Christen Studenten Vereeniging (the Dutch Christian Students' Union) sent Dr. C.L. van Doorn to serve Christian youth and students in Indonesia. In 1926 he formed the Christen Studenten Vereeniging [op Java] (Christian Students' Union [in Java]). In the same year Dr. John R. Mott, a prominent figure in the ecumenical movement and the chairperson of the World Student Christian Federation, and some other leaders, visited Indonesia for mission and youth programs. During the meetings,

${ }^{3}$ For comprehensive and detailed information on this consulate, see Jongeling 1966.

${ }^{4}$ For more information regarding the Chinese-Indonesian churches, see chapter nineteen. 
including a youth conference and the NIZB conference, they promoted the idea of oikoumene or church unity. This visit made a very deep impression and the motto of the WSCF, ut omnes unum sint (quoted from John 17:21), began to be known among Indonesian Christians. A few years later, in 1928, the Christen Jonge Vrouwen Federatie (the Young Christian Women's Federation), led among others by Mrs. Gunung Mulia and Ms. A.L. Fransz, was formed and accepted as a member of the World Young Women's Christian Federation).

Last but not least we must mention the role of the International Missionary Conference (IMC). In the first conference in Edinburgh 1910 no indigenous Christian from the Dutch Indies or Indonesia was present. The delegates from Indonesia consisted only of some missionaries, but Dr. Todung Sutan Gunung Mulia attended the second conference, in Jerusalem in 1928. He was impressed by the serious attention of this conference to various social-politicaleconomic issues connected to the essence and goal of mission, as well as to the presence of the representatives of some young churches. That is why in his speech at a NIZB conference, soon after he returned from Jerusalem, he sharply criticised the policy of the missions that did not seriously take into account some important international or global developments. ${ }^{5}$

In other words, through Dr. Gunung Mulia the Jerusalem conference encouraged the young Indonesian churches to strengthen their consciousness of unity and cooperation, and to reflect more seriously on their tasks in order to achieve autonomy. No wonder that the third IMC conference in Tambaram in 1938 was attended by more indigenous Indonesian Christians (there were twelve, among others are Ms. A.L. Fransz and Dr J. Leimena) besides some mission leaders who worked in this country. More than the former, this conference encouraged the young churches including those in Indonesia to be more serious in endeavouring to express their unity.

As the follow-up to these international conferences some important conferences took place in this country. One of them was the WSCF conference for the Asia region in Citeureup, close to Batavia/Jakarta, in 1933, attended by delegates from many western and Asian countries. In this conference the CSV op Java chaired by Dr. J. Leimena was accepted as a member of WSCF. This conference made a deep impression on the participants and Dr. Hendrik Kraemer, one of the missionary leaders who continually urged and encouraged the missionary societies to give autonomy to the young churches, praised this conference for its success in efforts to facilitate and to support the unity of the young Christians. Later on, since 1947, the CSV op Java became the Madjelis Pemoeda Kristen Oikoumene (Council of Ecumenical Christian Youth)

${ }^{5}$ Published in De Opwekker November/December 1928:518-537, and quoted by Ukur in Aritonang (ed.) 2000:13. 
and from 1954 became the Gerakan Mahasiswa Kristen Indonesia (GMKI, Indonesian Christian Student Movement). Many of its leaders and leaders became prominent leaders in the ecumenical movement, like Fridolin Ukur, Liem Khiem Yang, Sabam Siagian, Sabam Sirait, and Nico Rajawane.

Following up from the Tambaram conference, in January 1939 the leaders of some churches in Java met in Batavia/Jakarta to discuss the possibility of forming a council of churches and missions in Indonesia. They formed a working committee that consisted of some prominent leaders, but this plan had to be postponed due to the outbreak of World War II.

World War II (1939-1945) and the Japanese military occupation (19421945) hampered the progress of the ecumenical movement but also motivated some new steps. The short period of Japanese occupation became a catalyst for the development of ecumenical aspirations to accelerate, to widen and to enhance the spread of the idea of Christian unity. The churches were forced to implement their respective self-supporting and self-governing strategies. The usual difficulties and pressures had a significant role in making concrete the idea of Christian fraternity (brother/sisterhood). The unity of the Indonesian Christians was also expressed through some organisations formed by the Japanese military government, such as the Kiristokyodan Rengokai (Christian Council or Union) in Minahasa, South Sulawesi, Kalimantan and the Moluccas, which gave the churches valuable experience of how to live in an ecumenical spirit and atmosphere.

The presence and activities of some ministers sent by the Nippon Kirisuto Kyodan (the Japan Christian Church) also strengthened the ecumenical experience and widened the understanding of Indonesian Christians, although it was frequently burdened with political load. One of the ministers, Rev. H. Shirato, chairperson of the Rengokai, said: "Indonesian Christians, be united to support Dai Nippon!" But Shirato and his colleagues did not only ask the Christians to support their government, they also helped and defended the Christians in relation to the government, especially against the brutal acts of military personnel.

\section{Preparations towards DGI ${ }^{6}$}

One year after the proclamation of Indonesian Independence, and after the release of the European missionaries from internment, a missionary conference took place in Batavia/Jakarta on 10-20 August 1946. This conference

${ }^{6}$ This section is mainly based on Hartono 1984:57-71; Holtrop 1982:22-82; Ngelow 1982:39-44; Ngelow 1994:261-263, Ngelow in: Henky C. Wijaya (eds.) 1996:47-50; Ukur in: Aritonang (ed.) 2000:18-23; and Hoekema 1997:233-247. 
was initiated by the Zendingsconsulaat and there were two main issues to be discussed: (1) the place and task of the mission and missionaries in the new independent Indonesia, and (2) the plan to found an assembly or ecumenical body of the churches. Regarding the first issue, J.C. Hoekendijk, who was to become a prominent missiologist, introduced his theology of the apostolate and the so-called comprehensive approach that emphasized the task of the church as the gospel propagator to face and to care for humankind and the world as a holistic and comprehensive unity. This concept and approach was adopted later by DGI and its members, and is maintained up to the present.

Regarding the second issue, the discussion was based on an idea from $\mathrm{M}$. de Niet (Zendingsconsul 1939-1949). As a result of his meditations during the Japanese internment he suggested in December 1945 the founding of a Balai Kristen (Christian Chamber). This Nota de Niet proposed that the members of this chamber would be the Indonesian churches as well as those foreign churches that were doing mission and evangelism in this country. This chamber would be led by a secretariat with a number of secretaries who are expert in their respective fields (dogmatics, missiology, pedagogy, social environment, and administration). The main centre would be in Batavia, equipped with various facilities (library, museum, lodge, etc.) while in some regions there would also be founded a provincial Christian council as part of the national chamber.

The Gereja Protestant Indonesia (Indische Kerk) approved this idea but the conference preferred other options, either the forming of a Gereja yang Esa (One United Church) in Indonesia, or a federation of the churches in Indonesia. De Niet himself was aware that it was not easy to form one united Indonesian Christian Church. That is why in his Nota he already warned, "One truly Indonesian Christian Church cannot be formed by a group of people or on human authority overnight or with acclamation or a majority vote. That church must grow by the grace of God, and will do so, although its result will possibly be different from what the Christians are thinking." Finally the conference drew some conclusions (without taking any decisions),

1. Ecumenical togetherness of the churches in Indonesia, already expressed before World War II in various forms, should be continued and widened.

2. The target of that ecumenical togetherness is the founding of one single church in Indonesia.

3. The council of churches and missions in Indonesia is planned as a cooperating body of the churches in Indonesia and the sending churches

${ }^{7}$ M. de Niet, Oecumenische Samenwerking en Eenheid in Indonesië (Batavia: Zendingsconsulaat, 30 December 1945), quoted in: Holtrop 1982:89 and Ngelow 1982:90. 
in Europe with a goal to intensify ecumenical conversation and cooperation among the churches.

4. Due to political conditions that hampered the gathering of the national council of churches and missions, it is advised that the churches and the embryonic churches (bakal gereja-gereja) in some regions as far as possible form regional or provincial councils to do and promote the common task.

Meanwhile, before the August 1946 conference, in certain regions like in Yogyakarta, the so-called Conference of the Protestant Churches formed a Dewan Permoesjawaratan Geredja-geredja di Indonesia (Consultation Council of the Churches in Indonesia). In this conference, attended by quite a number of native Indonesians, some participants expressed their aspiration to be more responsible in evangelism and also their complaint that the foreign missions hampered the effort of the churches towards unity and reduced the interest of the Indonesian churches in handling themselves the tasks of mission and evangelism. As a result, therefore, this conference concluded that the foreign missions should no longer come to this country. They might send their missionaries, but only to be assigned to and managed by the churches in Indonesia.

This conclusion raised tension between the Dewan Permoesjawaratan and the missions. To neutralise the tension both sides gathered in May 1947 in a spirit of "partnership in obedience," and they came to an agreement called the Kwitang Accoord. In this document it was agreed, among other things that the churches in Indonesia and their foreign church partners would form a council of churches that consisted of synod with representatives from both sides. Although two small groups produced this document, it could be perceived as a turning point in the relationship of the missions and the churches in Indonesia.

At the end of the August 1946 conference in Jakarta some prominent church members from eastern Indonesia proposed a conference in their region. They agreed to have a special conference in March 1947 with two main agenda items: (1) to declare the unity of the churches and the emergent churches; and (2) to form a council of churches and emergent churches as branches of the Balai Geredja Keristen di Indonesia (Chamber of the Christian Churches in Indonesia). In accordance with this plan, 54 delegates from 16 churches and some missionary societies gathered in Malino (close to Makassar), and on 17 March 1947 they founded the Madjelis Oesaha Bersama Geredja-geredja Keristen, yang berpoesat di Makassar (Council of Common Efforts of the Christian Churches, centered in Makassar), shortened as Madjelis Keristen.

This ecumenical body accepted as members all mission organisations which aimed to serve the churches. In its constitution it was also formulated that one of its goals was to inquire into the founding of one Christian Church in 
Indonesia. In line with this, the conference decided that the position of the Madjelis Keristen should be as a branch and a pilot project of the coming national ecumenical body: to do on a small scale what should be done later by DGI. In fact, the prominent leaders in the Madjelis Keristen played important roles in the founding and the running of DGI.

Another important decision of the Malino conference was the founding of an ecumenical theological school for the churches in eastern Indonesia that was later realised as Sekolah Tinggi Theologia Indonesia Timur (STTIntim) in Makassar.

Besides those conferences and movements in Java (Yogyakarta) and eastern Indonesia (Makassar), there were some ecumenical gatherings in other regions, like North Sulawesi and East Sumatra. The Chinese churches held in May 1948 a conference in Jakarta as a continuation of the movement before the war, followed by a conference in September 1949 that formed the Dewan Geredjageredja Kristen Tionghoa di-Indonesia (DGKTI, Council of Chinese Christian Churches in Indonesia). Besides aiming to tighten the relationship and to promote unity among the Chinese churches, it also wanted to seek a relationship with the churches in Indonesia, and promote evangelism. The representatives of DGKTI and its members also attended the conference to found DGI and declared their willingness to join that council. However, DGKTI maintained its existence until it changed to become the Badan Permusjawaratan Persatuan Geredjani (BPPG, Consultation Body of Church Union) in 1954. BPPG brought a number of the Chinese churches in Java together in the Sinode Am Gereja Kristen Indonesia (General Synod of the Indonesian Christian Church) in 1962, resulting in the following years into a more real unity.

The Gereja Protestant Indonesia (GPI, Indische Kerk) also had its share in the process of founding DGI. Although GMIM had already became autonomous in 1934, followed by GPM in 1935 and GMIT in 1947, until 1948 GPI-while giving birth to another church, the GPIB-still maintained its existence as a 'holding church' for those regional churches, although it also supported the above-mentioned Nota de Niet. Following an idea proposed by Rev. A.Z.R. Wenas, chairperson of GMIM, GPI took a new step in its second general synod-conference in June 1948, by combining autonomy and unity. On the one hand GPI continued like the covering peel of an orange fruit, in gathering the autonomous units together-therefore functioning differently from the unity models of the mango or the grape-and on the other hand it supported its units joining DGI as was done by GPI itself. GPI even declared its willingness to end its existence if the churches in Indonesia would achieve unity in a form more perfect than GPI. 


\section{The founding of the Dewan Gereja-gereja di Indonesia, DGI}

After establishing a planning committee that consisted of representatives of the above-mentioned organisations or councils, the committee and around forty church leaders and delegates held a preparatory conference in Jakarta in November 1949. Some of them had just returned from the assembly to found the World Council of Churches in Amsterdam and brought some new ideas and concepts from that assembly that it was assumed could enrich the ecumenical vision to be formulated and implemented in the coming national council. One of the topics discussed in that preparatory conference was the essence of the ecumenical movement among the churches, based on a working paper prepared by Rev. J.L.Ch. Abineno. ${ }^{9}$

The conference came to an understanding that, although nationalism has a contribution, the ecumenical movement in Indonesia was not primarily based on nationalism but on the consciousness of Christian unity as the body of Christ. The conference also agreed that the main goal of this movement is the forming of one Christian Church in Indonesia, based on the conviction that the essential unity already existed, and the long process toward unity should be started with the formation of a cooperating body. The conference also realised that the movement and the unity did not happen in the form of a conference but in and by the people of the churches themselves. It was already realised too in this conference that this ecumenical movement did not only represent a movement to unite the Protestants, but all Christians, even the Roman Catholic Church and the dissenting groups. In the closing message of this conference it was even emphasised that the church does not seek for unity for the sake of unity itself, and does not exist for itself but for the whole world, and stands in the midst of the world as the servant of the Gospel of the Kingdom of God.

This preparatory conference also discussed some other agendas and programs that were expected to be handled later by the coming council, i.e. relations with the various existing and developing regional councils, spiritual care for military personnel, health and social service, publishing and communication media (including radio), schools and education, theological education, the Bible society, youth, international relations, official language, church and politics, division of tasks and the composition of commissions. All of these essential and operational matters were formulated in a draft constitution

${ }^{8}$ This section is mainly based on Hartono 1984:76-84; Ngelow 1982:31-38; Ngelow 1994:241-261; Ukur et alii 1979:573-575; and Ukur in: Aritonang (ed.) 2000:23-31.

9 Abineno later became one of the prominent leaders in the ecumenical movement, especially in Indonesia. He held the position of general chairperson of the DGI in 1960s and 1970s, succeeding Todung Sutan Gunung Mulia. 
and by-laws. A number of international ecumenical leaders like W.A. Visser 't Hooft and C.W. Ranson also attended this conference, where they shared information about the global ecumenical movement and contributed their ideas and advice regarding those matters.

As the follow-up to the preparatory conference, the founding conference of DGI as a national council of churches was held on 22-28 May 1950 in the campus of HTS/STT Jakarta. One of the crucial points of the discussion was whether this council would only consist of churches or also of missionary societies. Eventually it was agreed that the council would only accept Indonesian churches as members. In line with this, it was decided that the Zendingsconsulaat would be liquidated and its tasks, including the task of representing the churches to the government, would be taken over by the DGI. Regarding mission and evangelism previously undertaken by various missionary societies, the conference came to an understanding that it is basically and prominently the task of the churches. To coordinate this task the DGI would set up a permanent commission and the churches would gather in this commission along with the foreign mission societies.

Regarding the ecumenical goal, it was agreed and formulated in the constitution that the ultimate goal of this council is pembentukan Gereja Kristen yang Esa di Indonesia (the forming of the One Christian Church in Indonesia). Following the acceptance and approval of the constitution, the conference that consisted of the representatives of 27 churches declared the formation of the DGI through a Pengumuman (Announcement) ${ }^{10}$ as follows:

We, participants of the Conference for the formation of the Dewan Geredjageredja di Indonesia, herewith announce that now the Dewan Geredja-geredja di Indonesia is already founded as a place of consultation and common effort of the churches in Indonesia towards the unity of the churches in Indonesia, as stated in the constitution of the Dewan Geredja-geredja di Indonesia already decided by the conference on 25 May 1950. We believe that the founding of the Dewan Geredja-geredja di Indonesia, as an effort towards the implementation of God's message to His people, is merely God's grace. We trust this council into the hand of God the Father, Son, and Holy Spirit. May God always keep its going out and coming in from this time on and forevermore, for the glory of the name of God in this world. Djakarta 25 May 1950.

Besides appointing the executive committee (where Todung Sutan Gunung Mulia was appointed first chairperson), this conference took time to discuss a the release of a bulletin News regarding a declaration of the founding of the

${ }^{10}$ In some publications, e.g. Ukur in: Aritonang (ed.) 2000:27, and Almanak Kristen Indonesia 2003. Jakarta: PGI, 2002:10, this announcement is called Manifes Pembentoekan DGI or Manifest Pembentukan DGI, and there is certain difference of wording between the versions. English translation by JSA. 
Republik Maluku Selatan (Southern Moluccas Republic, RMS, a separatist state) on 25 April 1950, but then agreed that the conference would entrust this issue to be handled by the newly elected Executive Committee.

\section{Some developments and challenges, especially on the concept of unity ${ }^{11}$}

In the founding of the DGI two aspirations were brought together, i.e. mengesa (to be one) and mandiri (to be self-reliant). In the founding conference of 1950 (later also counted as the first general assembly of the DGI) the goal of the council was also declared, but the precise meaning or content of the goal and how it was to be achieved was not yet specified. In the following years and assemblies there was much discussion and struggle regarding these questions. In the second conference, 20-30 June 1953, for example, it was formulated that, "what is meant with the forming of the One Christian Church is the forming of one Church of Christ in Indonesia that has one confession and one basis of church order." Based on this, the DGI formed a special committee of Faith and Order, modelled on what was done in the WCC. The task of this committee was to adjust and to unite the confessions (statements of faith) and church orders of the members in order to have a common ground of unity. But then it was realised that this comparative approach did not fit the essence and the nature of the church, because the norms of church unity are not determined by the historical and empirical reality of the church.

From time to time, from conference to conference, the discussion of the essence and meaning of church unity and of how to express its manifestation went on, without any final result or agreement. We will not relate how many working papers and documents have already been written and presented on this subject. On the one side there was an emphasis on spiritual or essential unity, whereas on the other side there was an emphasis on the uniformity of some institutional and more operational aspects. In the 1960s there was, partly as an echo of the third WCC assembly in New Delhi, also an idea that the unity should be clearly expressed in each place or at the local level, not at the top or synod level. The DGI tried to implement this idea through a practical consensus that each member-church should refrain from planting new congregations in the areas of the other churches, so that the local congregations from the different denominations could be more directed toward integration. Or at least all members should be willing to come to an agreement about the mutual recognition of the members and ordained ministers of other fellow DGI member churches. But this idea was in conflict with the

11 This section is mainly based on Hartono 1984:84-99; Ngelow 1982:45-86; Ukur et alii 1979:576-594; and Ukur in: Aritonang (ed.) 2000:31-72. 
high desire and ambition of each denomination to have local congregations in as many regions or provinces as possible. From 1984 onwards, this mutual recognition was theoretically agreed to, as one of the so-called Five Documents of Church Unity.

Meanwhile the DGI continued to find an acceptable and suitable formula for church unity. To achieve this aim, in 1960 a new committee was formed to design a scheme for One Christian Church as the goal of the DGI. In the fifth general conference of the DGI in 1964 this committee proposed two concepts: a synod (like the Lambeth Conference in the Anglican Church) or a federation. But this assembly did not discuss these two concepts in detail, it rather discussed papers from three speakers: Rev. G.H.M. Siahaan from HKBP, Rev. P.H. Rompas from GPI, and Dr. Soedarmo from GKJ. Although the discussion created tension, this conference succeeded in coming to the conclusion that each member-church of the DGI, without any exception, wanted soon the formation of the One Christian Church and was committed to enhance the effort towards this formation, while also understanding each other in respect to the difference of opinion regarding the speed, ways and procedure of the formation. This consensus showed that the main role would be played by the member-churches, with the DGI playing only the role of facilitator.

Based on this consensus, from 1964 onwards, the DGI took some further steps. Besides continuing the effort to provide a concept of Faith and Order, DGI with its members also tried to form a concept of liturgy. But soon they became aware that what should be the result could not be one Church Order, one Statement of Faith, and one Liturgy, because it would lead to a uniformity, something already objected to since 1953. Therefore they tried to find another model of unity, i.e. unity in diversity, a model that reflected the influence of the "New Delhi 1961 Statement on Unity." Based on this, in 1967 DGI's Commission on Unity proposed a concept of Tata Sinode Oikoumene Geredja-geredja di Indonesia (Ecumenical Synod Order of the Churches in Indonesia), henceforth Tata Sinogi, in the sixth conference or assembly of the DGI in Makassar. It was realised that this ecumenical synod was not yet identical with the One Christian Church, but compared to the past it was a great step forward. In this concept were outlined, among other things, some principles as follows:

1. The togetherness of the churches in Indonesia in the form of a council would be enhanced to be an ecclesial institution in the form of a synod.

2. The decision of the prime meeting (sidang utama) of this synod would bind the members.

3. Its fundamental doctrine and confession are the Word of God, the Apostles' Creed, and Common Understanding of Faith. 
Quite disappointingly, this general assembly did not accept the concept, which was only recommended "as a document to be discussed and struggled further with in opening more possibilities for the member-churches." In the following meetings, even in the seventh assembly of the DGI in Pematangsiantar 1971, it was concluded, "the time has not yet come to take a decision on the forming of the Ecumenical Synod." "This subject would become our churches' concern. Apparently the efforts towards the manifestation of unity so far endeavoured are not yet so intensive and comprehensive."

From 1971 onwards the DGI, with the members, continued their efforts to find a more suitable and acceptable model of unity. Through various ways of monitoring it was found that the churches in Indonesia preferred to put more emphasis on the manifestation of their unity in "unity in each location (in the local level)" and "unity in action" rather than unity in organisation, liturgy and confession. Therefore the DGI and its members had to make a reorientation. They left the old concept of "interdenominational ecumenism" and the emphasis on unity in organisation, liturgy and confession, and turned to a new approach, the integration of unity in worship, witness (testimony, marturia) and service (diakonia) while also developing the concept of "unity in diversity." In terms of organisation only one commission handled the tasks of witness and service and it was understood to be an evangelical role of the ecumenical movement. In other words, the unity of the churches is for the sake of witness and service to the world, whereas in the understanding of the form of unity, it was realised that it should be also more and more manifested in strong motivation, participation (support) and the mandate of the members of the DGI, not merely in the structural form.

Through a number of discussions and seminars during the 1970s it was also realised that the unity of the church, or the One Church itself in Indonesia, essentially existed already according to the essence of the Church; the task of the churches is to manifest and to implement it. Through this awareness it was also realised that the ecumenical movement should avoid the danger of institutionalism, uniformity and centralistic-pyramidal unity or community. The consequence of this consciousness was the reformulation of the goal of the DGI, including its constitution. There was already since the 1970s an idea to change the terminology from pembentukan (forming) to penampakan or perwujudan (manifestation). In line with this, it was proposed that the term dewan (council) in the name of DGI should be changed to persekutuan (community). But it took time to internalise these two ideas or proposals, until they were agreed to and decided on, in the tenth general assembly in Ambon 1984.

In line with the reformulation of the meaning and goal of the ecumenical movement, since the 1970s there has been a strong tendency towards a greater social-humanitarian concern and service. This tendency, as was also reflected in the theme of the DGI's general assembly in Pematangsiantar 1971, 
"Disuruh ke dalam dunia" (Sent into the world), was influenced by the theme and concern of the WCC general assembly in Uppsala 1968. We will see this further in the next section.

After some preparation and discussion in the period between the DGI's general assemblies of 1976 and 1984, in the Ambon general assembly of 1984 the name of the DGI was changed to become the Persekutuan Gereja-gereja di Indonesia (PGI). One of the arguments and explanations for this change was that the term Persekutuan (Communion) is more ecclesiastical and biblical than Dewan (Council). Moreover, with this new term the idea of unity is more obvious and more manifest. Together with this change, the assembly also approved a series of documents called the Lima Dokumen Keesaan Gereja (LDKG) (Five Documents of Church Unity) that consist of:

1. Pokok-pokok Tugas Panggilan Bersama (PTPB) (The Basic Tasks of Common Calling)

2. Pemahaman Bersama Iman Kristen (PBIK) (The Common Understanding of the Christian Faith)

3. Piagam Saling Mengakui dan Saling Menerima (PSMSM) (The Charter of Mutual Recognition and Acceptance)

4. Tata Dasar Persekutuan Gereja-gereja di Indonesia (TD-PGI) (Constitution of PGI)

5. Menuju Kemandirian Teologi, Daya dan Dana (MKTDD) (Towards SelfReliance in Theology, Human Resources, and Finance)

These documents were from time to time revised, updated, and reformulated according to the development of the PGI and its members' understanding of their context and challenge. ${ }^{12}$ For example, in and after the general assembly of 2000 in Palangkaraya the content and composition was modified. The second document, Pemahaman Bersama Iman Kristen (PBIK) was placed first, based on the assumption that the One Christian Church (Gereja Kristen yang Esa) must be built on a common understanding of the faith. The title of the series was also changed to become Dokumen Keesaan Gereja (DKG) (The Documents of Church Unity), anticipating the possibility of adding or reducing the number of documents therein. But then the general assembly of December 2004 decided to put the document of Pokok-pokok Tugas Panggilan Bersama (PTPB) back as the first, while also modifying the title to become Dokumen Keesaan Gereja 2004-2009.

${ }_{12}$ The last version using the name LDKG was the product of the twelfth general assembly of 1994 in Jayapura, i.e. Lima Dokumen Keesaan Gereja, Persekutuan Gereja-gereja di Indonesia-Keputusan Sidang Raya XII PGI Jayapura, 21-30 Oktober 1994. Jakarta: BPK Gunung Mulia, 1996. 


\section{Some Main Issues and Programmes}

\section{Relationship and cooperation among the streams and the denominations}

When the DGI was founded in 1950 there were 27 church organisations or denominations that agreed to join, and then registered to become the first members. Most of them were the so-called mainline Protestant churches (including the Methodist and Chinese churches). In the meantime the number of its members grew to be 81 in the year 2005, from among around 300 church organisations in Indonesia. From this figure we may see that in terms of numbers that only around $27 \%$ of the churches have become members of DGI/PGI, although in terms of membership those 81 churches cover more than half of the Protestants. As we see in chapter eighteen, besides the DGI/PGI there are also some other church unions among the Pentecostals, Evangelicals, and Baptists, and there are some other churches that do not join any union or communion of churches.

Generally speaking, all of the approximately 300 churches agree to and support the idea of ecumene. Many of them even use the word oikoumene or ecumenical in their activities (like 'ecumenical revival meeting,' 'ecumenical community', 'ecumenical gathering' etc.). But we may also say that among those approximately 300 churches more than half are products of schism. We may find schisms among all categories of churches: the mainline, the Pentecostal, the Evangelical. This fact leads us to a basic question: what do those churches mean by oikoumene or church unity?

Among these church unions sometimes we find a consciousness to build a cooperation, network, or forum of gathering. In the 1990s, for example, six church unions or communions formed the so-called Forum Komunikasi Lembaga-lembaga Gerejawi (Communication Forum of Ecclesiastical Institutions) that included the Konferensi Waligereja Indonesia (Indonesian [Roman Catholic] Bishops' Conference). Besides that there is also the Forum Komunikasi Kristiani Indonesia (Indonesia Christian Communication Forum). In August 2000 a number of church leaders-from the mainline Protestant, Pentecostal, Evangelical, Baptist, Salvation Army, and Orthodox communities-issued a declaration (that was called Deklarasi Kempinski, using the name of a hotel in Jakarta where they gathered) expressing their agreement to build a more permanent organisation that could unite all Christians and churches in this country. ${ }^{13}$ But, as had already repeatedly happened before, this kind of forum or agreement tends to be incidental when facing certain burning issues or urgent and emergency situations (like the burning of church

${ }^{13}$ Ign. Dachlan Setiawan, "Deklarasi Kempinski," in: Panggilan (magazine of the Indonesian Evangelical Fellowship/PII), April-June 2001:18-21. 
buildings, inter-religious conflict, political manoeuvres of Islam, the tsunami disaster). The difference of doctrine or confessional and denominational heritage hampers them from taking further steps.

Even the DGI/PGI and its members have, from time to time, faced a dilemmatic situation. On the one hand they struggle for the unity of the churches, but on the other hand they have to accept new member churches that were mostly founded in an excess of schism. The more the number of the member churches increases the farther the DGI/PGI walks from its former and original goal. To solve this problem, at least tentatively, the general assembly of the PGI in December 2004 declared "ecumene in action," i.e. the implementation of the ecumenical spirit and movement in concrete action together. It was shown, for example, in the relief action of the churches to handle the impact of the earthquake and tsunami disaster since the end of December 2004.

Dealing with the relationship and cooperation of the DGI/PGI with the Majelis Agung Waligereja Indonesia/Konferensi Waligereja Indonesia (MAWI/ KWI), we need to add some more information. ${ }^{14}$ Before the Second Vatican Council (1962-1965) the relationship of the Protestant churches and the Roman Catholic Church was characterized by tension and rivalry. ${ }^{15}$ But soon after the Second Vatican Council there was a very significant shift in atmosphere. From the late 1960s up to the present for example, the DGI and the MAWI every year issued a joint Christmas Message to all churches and to the whole nation. Reflecting on the participation or role of the church in national life and development, the DGI and the MAWI through their respective special departments frequently sat together and formulated their common understanding and plan of action.

The close cooperation and togetherness was also seen in regard to some crucial issues, as we see in the following examples. ${ }^{16}$ Dealing with the Joint Decision or Instruction of the Minister of Religious Affairs and Minister of Internal Affairs No. 1, 13 September 1969 regarding the requirement to get permission for building places of worship, the DGI and the MAWI issued together a Memorandum on 10 October 1969 that noted certain contradictions and vagueness in the joint-decision and proposed some ideas to maintain the right of religious freedom and to maintain a good inter-religious relationship. ${ }^{17}$

\footnotetext{
${ }^{14}$ Here is not the place to describe the history of the MAWI/KWI, its place in the structure of the Roman Catholic Church in Indonesia, and its concept or understanding of ecumene. It is clear, however, that the nature of the DGI/PGI as a council or communion of many Protestant churches is different from that of the MAWI/KWI as a conference of bishops of one Roman Catholic Church.

${ }^{15}$ For example, in Verkuyl 1961, the Roman Catholic Church was still regarded as one of the heresies. It was a heritage from the era of missionaries.

${ }^{16}$ Some more examples can be found in chapter sixteen of this book.

17 The complete text of the Memorandum: see in Weinata Sairin (ed.) 1994:443-446. Up
} 
The second example is regarding the Draft of Marriage Law (Rancangan Undang-undang Perkawinan) of 1973. In this draft it was stated that marriage is legalised by its registration in the government office and by an officer of marriage, and that the difference of religion does not become a hindrance for marriage. When the government issued this draft, some Islamic leaders and organisations reacted sharply; they alleged that there was a 'play' or manoeuvre by certain Christian (especially Catholic) circles behind it and they appealed to the government to revise this 'secularised' draft so that marriage would become determined by religious law. Towards this severe reaction of the Muslim side, and some indication that the government tends to accommodate the aspiration of the Muslims, the DGI and the MAWI issued a document "Pokok-pokok Pemikiran BPH DGI dan MAWI" (Basic Thoughts of the Executive of DGI and the MAWI) that basically appealed to the government to be very careful in making a decision on this Marriage Law, so that it will not be contrary to the Constitution of 1945, especially article 29 verse 2 that guarantees religious freedom. ${ }^{18}$

The third example deals with the Decisions or Instructions of the Minister of Religious Affairs Nos. 70 and 77, 1 and 15 August 1978, ${ }^{19}$ which on 2 January 1979 became a part of a Joint Decision/Instruction (No. 1/1979) of the Minister of Religious Affairs and the Minister of Internal Affairs about the rules for the spreading of religious propaganda and foreign aid for religious organisations in Indonesia. ${ }^{20}$ In response to these decisions DGI together with MAWI issued a review that principally asked the government to cancel them based on three arguments: they are contrary to the religious freedom guaranteed in the Constitution, the classification of regions in Indonesia according to religion is contrary to the essence of the Republic of Indonesia as a unitary state, and the church as a religious institution has a universal dimension. ${ }^{21}$

to the time of writing this chapter the Christians (including Catholics) repeatedly appealed to the government to cancel this Joint Decision, while Muslims asked for the opposite. The Muslim party even wanted the Joint Decision to be upgraded to become a Law. The draft of the Religious Harmony Law provided by the Department of Religious Affairs in 2006 seems to accommodate this Muslim aspiration.

${ }_{18}$ The complete text of the "Pokok-pokok Pikiran," see in: Weinata Sairin and J.M. Pattiasina (eds.) 1994:248-249. Eventually the Marriage Law was issued as No. 1/1974 in January 1974 and since then, up to the present, brought many complicated problems, especially regarding inter-religious marriage.

19 The complete texts in: Weinata Sairin (ed.) 1994:50-59.

20 The complete text of the "Keputusan Bersama Menteri Agama dan Menteri Dalam Negeri Nomor 1 Tahun 1979 tentang Tatacara Pelaksanaan Penyiaran Agama dan Bantuan Luar Negeri Kepada Lembaga Keagamaan di Indonesia," in: Weinata Sairin (ed.) 1994:63-68.

${ }_{21}$ The complete text of the "Tinjauan mengenai Keputusan Menteri Agama nomor 70 dan 77 tahun 1978," in: Weinata Sairin (ed.) 1994:453-476. 


\section{Education and formation ${ }^{22}$}

As already mentioned, among the missionary societies we find a strong consciousness that they had to work together and that one of the fields of cooperation was education, especially theological education. After the founding of the DGI, this ecumenical body paid quite serious attention not only to the field of theological education but also to general education or schooling. While many of the churches, especially members of DGI/PGI, were also busy developing their educational programs, the DGI/PGI also took a number of strategic steps. The establishment of the Majelis Pusat Pendidikan Kristen/MPPK on 5 June 1950 (since 2000 the Majelis Pendidikan Kristen/MPK, the Council of Christian Education), to coordinate Christian schools from elementary to high school levels all over the country, was also co-initiated by the DGI. So was the founding of the Universitas Kristen Indonesia (Indonesia Christian University) in Jakarta in 1953 and the Badan Kerjasama Perguruan Tinggi Kristen di Indonesia (Cooperative Body of Christian Universities in Indonesia) in the 1970s.

Especially in the field of theological education, the DGI/PGI developed a close relationship with the Perhimpunan Sekolah-sekolah Theologia di Indonesial Persetia (the Association of Theological Schools in Indonesia) that was founded in 1963. Many programmes of the Department of Education and Formation of the DGI/PGI were held together with Persetia, for example regarding the curriculum for Sunday-Schools in the churches and religious education in the general schools (from elementary school up to the universities).

This Department of Education and Formation of the DGI/PGI (regardless of its frequent change of name) also paid serious attention to the training (pembinaan) of church members, covering spiritual, practical, organisational, missionary, and ecumenical formation. In cooperation with its member churches and with some Christian and para-church organisations, this department held a series of regular training events for Sunday-School teachers, youth and teenagers, women, lay people, and also pastors (including those who served in the military and police). It also provided booklets and modules of training to be used by the churches. To support this program the DGI/PGI provided several special buildings (like the Pondok Remaja in Cipayung and Wisma Oikumene in Sukabumi), and in 1971 it also founded a special institute, the Institute Oikumene Indonesia/IOI (later integrated into the Department of Education and Formation). Through this department the DGI/PGI, in cooperation with

${ }^{22}$ A summary of and reflection on this subject, esp. in the circle of the DGI/PGI, we may find in an article of S.M.T. Rajagukguk, "Membentuk Tujuan Pembinaan dan Pendidikan (50 Tahun Pelayanan Pembinaan dan Pendidikan DGI/PGI," in: Aritonang (ed.) 2000:217-235. 
its overseas partners, also distributed scholarship grants and supported students of general as well as theological schools and universities.

Since the 1970s there had been a dream to establish a special institute to train young Christians to become ecumenical cadres, like the Ecumenical Institute in Bossey, Switzerland. To prepare the implementation of this idea, the DGI/PGI founded a special institute, the Akademi Leimena, as a sort of 'think tank' that also equips church members in their roles in society, among other ways through the series of Konferensi Gereja dan Masyarakat (Conferences on Church and Society), since 1984 (see below). Unfortunately the realisation of this idea had to be postponed and the Akademi Leimena itself was liquidated due to some difficulties faced by the PGI (see further below).

\section{Participation in nation building and development $t^{23}$}

From the beginning that is from the time of DGI's preparation and formation, there was awareness that the ecumenical movement and its institutions should make a contribution to the process of nation building, including making some efforts to solve various social-political-economic-legal-cultural problems. During the 'revolutionary era' (1945-1949), especially since 1947 when Indonesia became a federal state (Republik Indonesia Serikat/RIS), there was a strong aspiration that Indonesia should become a unitary state (Negara Kesatuan Republik Indonesia), as was declared in its Constitution of 1945. The DGI was founded before Indonesia again became a unitary state on August 17, 1950, and its foundation was also motivated by the consciousness that Indonesia is a unitary state. This consciousness was reflected in the minutes of the first conference of 22-28 May $1950 .{ }^{24}$ The forming of the DGI, therefore, can also be viewed as a support and encouragement to the Negara Kesatuan.

Soon after the first conference, DGI formed a special commission that was called the Commission on Church and State (in the second conference of 1953 this was changed to become the Commission of Church and Society). In the fourth conference, 1960, under the theme "Unity of the Church-Unity of the Nation" it was stated:

The idea of church unity in Indonesia is essentially different from the one-nation building in Indonesia, because church unity is a unity of faith, not political unity.

${ }^{23}$ Information on this topic is summarised in Aritonang 2000:87-138. Regarding the thinking and ideas of some Christian leaders in the 1960s on this subject, see Sidjabat 1964 and 1968. Review of the concept, policy and program of the ecumenical movement, especially the DGI, regarding participation in the development in 1960s and 1970s is provided by Erari 1994; whereas the developments during the 1980s and 1990s can be found in a series of compilations of the CCS published by the DGI/PGI.

${ }^{24}$ PGI 1996a:23-81. 
However, between these two things there is a mutual relationship, because both of them are present in the one and same society. With that unity the churches in Indonesia can do their task of service more perfectly and help to strengthen the unity of the society and the state. ${ }^{25}$

This is also the reason why during the period of 1950-1960, characterised by a number of revolts, the DGI issued an appeal to the whole nation to maintain the unity of the state and nation, as well as the unity of the church, while also inviting the people, especially the Christians, to participate in the first general election of 1955 .

Ever since independence the DGI and its members held an understanding that one of the main pillars of the unitary state of Indonesia is the Pancasila (the Five Principles or the Five Pillars of national identity), the fundamental philosophy and ideology of the state. As already shown, during the preparatory meetings for the independence of Indonesia, from late May until August 1945, Christian leaders like Mr. Johannes Latuharhary fought to maintain Pancasila. This struggle continued during the 1950s, especially in the Konstituante meetings in 1956-1959. DGI also took the same position, because the prominent Christian leaders in the Konstituante, like Rev. W.J. Rumambi and Mr. J.C.T. Simorangkir, were also prominent leaders of DGI.

Since the 1960s the DGI, following the WCC, held a series of Conferences on Church and Society (CCS). In line with the slogan and program of "revolution" declared by President Soekarno, the DGI and its members (through the general conference as well as the CCS) also conceived revolution as their task, while also critically giving a theological understanding of this concept. The first CCS, combined with a consultative meeting of the DGI and the East Asia Christian Conference in November 1962, was held under the theme, "Christian Service in the Revolution." One of the conclusions was, "The church can live in every political system. But the church has a duty to give witness of warning against things contrary to God's plan and will."

The commitment of the DGI to participate in the revolution of Indonesia culminated in the fifth conference of 1964, under the theme, "Jesus Christ a Good Shepherd" and sub-theme "Christian Task in the Revolution." The 'brain' or star of this assembly was the retired Lieutenant General Tahi Bonar Simatupang, who was also one of the chairs of the WCC. One of the statements of this assembly said:

In this current situation, where the people are facing some heart-attracting hopes besides disappointment and worry, which are commonly found in every revolution, there is a Good Shepherd for man. Especially for the Christians, the Good Shepherd leads them to live constructively, creatively, realistically, and

${ }^{25}$ PGI 1996b:213-215. 
critically in this revolution. Essentially the Christians are very glad to participate in giving content to the revolution of Indonesia. The Christians are glad because various fields of culture were and are revolutionarily blooming.... At first glance we may see a parallel of the fundamentals, direction and goal of the Indonesian revolution in many aspects of what we may find in the revolution started by Jesus Christ.... To be more competently contributing to nation building during the revolution constructively, creatively, realistically, and critically the Christians should firstly be called to listen to the word of God. ${ }^{26}$

These "tetra-words" formulated by T.B. Simatupang (later 'constructive' was replaced by 'positive'), became DGI/PGI's jargon for several decades. Especially regarding critical attitude, the fifth assembly also focused its attention on the habit of corruption that was already extensively practised. But so far there has been no significant result, even up to the present, because even within the churches this 'endemic disease' is also quite common.

Not long after the fifth assembly a so-called coup d'état was attempted on 30 September/1 October 1965. This failed coup brought radical change in the political constellation in Indonesia. The DGI itself-as far as we can find data-did not say a lot or express a comprehensive review of it. One of the very few statements was "Pernyataan dan Seruan DGI" (Statement and Appeal of the DGI) on 7 October 1965 that, among other things, contained a criticism and condemnation of the Gerakan 30 September/Partai Komunis Indonesia (G30S/PKI, 30 September Movement/Indonesian Communist Party) and support for the government under the President Soekarno to maintain the Pancasila State. ${ }^{27}$

In the second CCS and the sixth conference of the DGI in 1967 we hardly find the revolution word, although it was not totally deleted or neglected, and there was very little attention paid to the failed coup. The more dominating themes, following the change of social-political-economic atmosphere and the emergence of the so-called Orde Baru (New Order) regime under Soeharto, were pembaharuan (renewal), pembangunan (development) and the like. The DGI and its members took the renewal of humankind, church and society, as the most important renewal, and this was understood as parallel with modernisation. The main pattern of DGI's theological concept regarding the position, role and task of the church in state and society had, however, not shifted from the former emphasis on the Kingdom of God that has already come, is, and will be coming.

As Christians we perceive the modernisation, revolution and renewal under the light of the Kingdom of God.... The Kingdom of God is among us. The Kingdom

${ }^{26}$ Quoted in Sairin (ed.) 1996b:365-368. Cf. T.B. Simatupang 1968:7-35. 298.

27 The complete text of the "Pernyataan dan Seruan DGI," in: Weinata Sairin (ed.) 1998:296- 
of God influences history, the unjust orders are overthrown and we are called to participate in the great change in history. We assess the modernisation, revolution and renewal under the light of the Kingdom of God to decide what within it we need to support and what we have to reject.... The knowledge of the Kingdom of God frees us from despair and cynicism. Therefore Christian ideas can contribute realism on the one hand and future-oriented hope on the other hand to the political ideas of our nation. ${ }^{28}$

Based on this theological concept the second CCS also formulated the understanding of the DGI and its members of their task in the field of politics, law, economics, and in the tide of modernisation. This concept also reflected an understanding and consciousness that the ecumenical movement is not only dealing with church internal issues but also with the problems and struggle of the people in the whole life of the nation. This was also reflected in the decision of the sixth general conference of DGI held around four month after the second CCS,

All of us are already involved in the process of modernisation and nation-building. We Christians participated in it with a sense of responsibility to God and to the future of our state and nation.... Besides living as responsible citizens Christians have to participate fully in the efforts to renew the structure of society, the political and economical system, and the values that dominate the culture and ideals of society. ${ }^{29}$

Precisely in the year of the second CCS and the sixth general conference a conflict containing religious aspects, especially between Islam and Christianity, broke out in several places, including Makassar where it is known as the Peristiwa Makassar 1967 (see also the following section). But this did not reduce the commitment of the DGI and its members to participate in the nationbuilding program; they even intensified their commitment in the coming years, especially when development became a key word, not only in Indonesia but all over the world. In 1970 the DGI and the KWI formed a special committee, SODEPAXI, as a follow-up of the SODEPAX Committee (Committee on Society, Development and Peace) founded by the WCC together with the Roman Catholic Papal Committee for Justice and Peace. SODEPAXI held a special study conference on development, Konferensi Studi untuk Pembangunan in Cipayung, West Java, on 9-15 May 1970.

This Cipayung Conference had a special significance since it showed a manifestation of a broader ecumene already long dreamed of, one that involved

${ }^{28}$ Quoted from S.A.E. Nababan (ed.) 1968; also quoted in: Aritonang (ed.) 2000:100-101. This Kingdom of God theme was then re-echoed and re-intensified in the theme of the ninth general assembly of the DGI at Tomohon in 1980 Datanglah Kerajaan-Mu (Thy Kingdom Come!).

${ }^{29}$ Quoted from Keputusan-keputusan Sidang Lengkap DGI ke-VI 29 Okt.-8 Nop. 1967 di Makassar (Sulawesi Selatan), Djakarta: DGI, n.d., pp. 83-85; also quoted in: Aritonang (ed.) 2000:103-104. 
both the Protestant and the Roman Catholic churches. The theme of this conference was Partisipasi Gereja dalam Pembangunan Nasional (Participation of the Church in National Development) and this theme became very popular between the DGI/PGI and its members during the 1970s and 1980s. This conference on the one hand appreciated the progress of modern science and technology and supported the development program of the New Order regime as a strategic step to overcome the poverty and misery of humankind as well as to uphold justice and humanity. But on the other hand it also warned of the potential danger implied in the process and concept of development, that of giving an exaggerated emphasis to physical development. The conference was also aware that the development did not only aim to overcome visible poverty but also to endeavour to make structural changes in human life. Out of this awareness the conference challenged the churches and tried to formulate a theology of development.

In DGI and its members this concept and theology of development was elaborated further in the seventh conference (from this time on it was called the general assembly) in Pematangsiantar 1971 and those that followed. The theme of this general assembly was Disuruh ke dalam Dunia (Commissioned to the World), following the theme of the WCC fourth general assembly in Uppsala 1968, and the sub-theme was Tugas kita dalam negara Pancasila yang membangun (Our task in the developing Pancasila state). There was a rising consciousness that Christian churches are not only called to be one but are also called to serve one world, troubled with various problems. One of the prominent leaders in DGI/PGI who persistently introduced and applied the theological concepts and ideas of the WCC to the DGI/PGI and its members, and built a critical theological thinking on the relationship between church and state was Soritua A.E. Nababan, its general secretary in 1967-1984..$^{30}$

Although from the beginning the DGI already showed its concern and responsibility to humankind and to the life of the nation and society, this assembly was perceived by its members as a turning point in the orientation of church life, from a more future and other-worldly orientation to a more current-real-world-orientation. The address of this assembly stated:

We are called to take part responsibly in the efforts to free humankind from their suffering caused by backwardness, poverty, disease, fear and legal uncertainty. We are called to fully participate in endeavouring justice in all fields of life: in economics and politics, in inter-human and inter-group life, in the social order and international life. We are called to strive for the demolition of falseness,

${ }^{30}$ One of Nababan's writings on this issue is Apa Kata Uppsala?, Djakarta: BPK, 1969. During the late 1980s and 1990s there was a sharp conflict between Nababan and Soeharto and this brought complication and troubles into PGI as well as HKBP (where Nababan held the office of ephorus 1986-1998). For this see chapter thirteen. 
hypocrisy, corruption and dishonesty. We are called to work hard to enhance the welfare of all humankind, physically and spiritually. ${ }^{31}$

Based on this new orientation, DGI and its members soon renewed the structure of their organisation and program and they formed some new working-units such as Pelayanan Masyarakat Kota dan Industri (Urban and Industrial Social Ministry) and Departemen Pelayanan (later Partisipasi) dalam Pembangunan (Department of Participation in the Development). DGI also founded a Development Centre to provide and to train development motivators in its member churches, especially for rural development. For around twenty years, until the 1990s, there were hundreds of motivators working in their own churches or inter-church until the big-budget departments and development centres were liquidated in the late 1990s, also because of mistakes and internal problems in the DGI/PGI and its members. After all it had become a projectoriented, very bureaucratic and top-down approach. Finally the development concept was revised and assessed as having failed to achieve its goal.

The third CCS in 1976, the fourth in 1984, the fifth in 1989 and the sixth in 1993 (also attended by the Roman Catholics) as well as the eighth general assembly of the DGI in Salatiga 1976, the ninth in Tomohon 1980, the tenth in Ambon 1984, the eleventh in Surabaya 1989 and the twelfth in Jayapura 1994 still echoed the same spirit and understanding of the churches regarding their ecumenical calling in the life of the nation and society. But from time to time we may hear a more critical review and evaluation of the concept and program of development as implemented by the New Order government. Already in the third CCS of 1976 we hear some critical notes regarding the excesses and victims of the development:

All over the world as well as in our country, the hope for a better future is mixed with various restlessness, tension and worry. The expectation for a just and prosperous society that was raised by Pancasila and the development program itself is facing the reality of a widening gap between the rich and the poor. The appeal for a sober life is sounded in the midst of striking luxury, legal uncertainty and the more marginalised condition of the homeless, the prisoners and some other groups. ${ }^{32}$

In tune with this, in two theological colloquia held by the DGI, Pertemuan Gerejawi tentang Partisipasi Gereja dalam Pembangunan (Sipoholon-Tarutung 1978) and Konsultasi Teologi mengenai Partisipasi Gereja-gereja dalam Pembangunan (Tentena-Central Sulawesi 1979), the attending churches focused

\footnotetext{
${ }^{31}$ Quoted from Notulen Sidang Raya ke-VII Dewan Gereja-gereja di Indonesia, 18-28 April 1971, pp. 93-95; also quoted in: Aritonang (ed.) 2000:107-108.

${ }^{32}$ Quoted from, Melihat Tanda-tanda Jaman. Pengamalan Pancasila dalam Membangun Masa Depan. Laporan KGM Klender 15-21 Maret 1976. Jakarta: BPK Gunung Mulia, 1976:97-99; also quoted in: Aritonang (ed.) 2000:110.
} 
their attention on poverty as the impact of development and as a theological problem. One of the conclusions of the Tentena consultation said:

The churches now arrive at a point of history where the problem of poverty, or more accurately the poor and suffering people, is evident: shortage in food, clothes, education and knowledge, nutrition and health, and also diminished involvement in decision-making. All of these become a more challenging and urgent reality in the society and on all levels of life. The shortage situation also becomes a burning problem for the churches all over the country. ${ }^{33}$

Reading those touching formulations may lead us to be impressed by the concern of the DGI and its members for the poverty and suffering of the people. Reality was not always such! The ninth general assembly at Tomohon (North Sulawesi) in 1980, for example, was marked by a quite luxurious opening ceremony, including expensive fireworks. Experiencing real poverty, and having total involvement and commitment to overcome it, is not as easy as making beautiful formulations. Anyway, DGI and the members continued to perceive Pembangunan as the key to abolishing poverty. The fourth CCS in Bali 1984 was held under the theme Harapan dan Keprihatinan Bangsa dan Gereja Memasuki Akhir Abad ke-20 (Hope and Concern of Nation and Church Entering the End of the twentieth Century, then also used as the sub-theme of the tenth general assembly at Ambon) and the sub-theme Panggilan Kita dalam Pembangunan Nasional sebagai Pengamalan Pancasila (Our Calling in the National development as the Application of Pancasila).

This sub-theme was once again proposed by T.B. Simatupang and the keyformula, Pembangunan Nasional sebagai Pengamalan Pancasila (PNSPP), was maintained by the PGI and its members until the 1990s. Eka Darmaputera ${ }^{34}$ even said that the success of PNSPP became one of the obsessions-not to say the only obsession-that Simatupang had until his death on 1 January 1990. Even the New Order government used this formula and put it into Garis-garis Besar Haluan Negara (Outlines of the Direction of the State) of 1988. ${ }^{35}$ Notwithstanding their awareness and concern over the excesses and deviation of the development program, the member churches still wanted to express their conviction that development would be successful in bringing the nation and society to a take-off (tinggal landas) ${ }^{36}$ for the achievement

${ }^{33}$ Quoted from, Realisme yang Berpengharapan-Laporan Konsultasi Teologi mengenai Partisipasi Gereja-gereja dalam pembangunan, Tentena 1-5 April 1979. Jakarta: DGI, 1981:226; also quoted in: Aritonang (ed.) 2000:112 and reviewed in Erari 1994:173-184.

34 Eka Darmaputera is one of the most prominent Indonesian theologians. He was one of the chairpersons of the PGI in 1989-1994 and then became vice-chairperson of the Consultative Board of the PGI. He passed away in July 2005. See also his role and theological thinking in chapter sixteen.

35 T.B. Simatupang 1987.

36 This term became a very popular jargon term in 1980s in the documents of the government 
of their dreams and ideals, on the condition that they were implemented as the application of Pancasila. Therefore it is not surprising that PGI and its members, or supporting-theologians, intensified their efforts to formulate the so-called Teologi Pembangunan or Teologi Pancasila. This was later used by the PGI and its members as an argument for accepting Pancasila as satusatunya asas dalam kehidupan bermasyarakat, berbangsa dan bernegara (the only principle in the life of society, nation and state) and to put it into their respective constitutions, as was required by law No. 8/1985 regarding social organisations. When Indonesia eventually collapsed or crashed, wrecked by a multi-dimensional crisis from 1997 onwards, some claimed that the mistake was not in the Pembangunan, Pancasila, or the related theology, but because the government did not run the development as an application of Pancasila.

If we look into the statements of the fifth CCS of 1989 and the sixth of 1994, as well as the messages of the eleventh general assembly at Surabaya in 1989 and the twelfth at Jayapura in 1994, actually there were many warnings related to the more serious problems regarding poverty, social-political-economic injustice, violation of human rights, the destruction of the environment, to sum up: the failure of the development program. We might say that the PGI and its members, together with the other churches and denominations as an ecumenical body, have more or less fulfilled their prophetic task. Most of the warnings became reality during the crisis period. The question is how seriously the government heard and noticed the voice of Christians and the churches and how effective was the method they used to communicate their message? In line with this, it may be asked how consistently the Christians and churches in Indonesia keep their distance and their critical function towards the government, and how seriously do they apply all of their statements and messages themselves? This series of questions will later be elaborated further.

Not long after the sixth CCS and the twelfth general assembly, precisely from June 1996, many churches suffered material loss and even loss of life, caused by a series of conflicts, most of them having religious dimensions (see the following sub-section). While the conflicts were still burning, a series of crises, initiated by the monetary crisis from 1997, devastated the whole nation and brought a change of regime and era. In such a situation the PGI and the members, as well as the other churches and denominations, strove to continue their role and contribution in the life of the nation. The Roman Catholic Church through the KWI even showed a more critical attitude that frequently inspired the PGI and the members to follow. In a pastoral letter before the general election of 1997, for example, when some critics of the government

as well as the PGI. After the multi-dimensional crisis of 1997 onwards this term was downgraded to be tinggal kandas (crashed or stranded) or tinggal di landasan (left on the runway). 
requested the people not to vote (Golongan Putih, Golput) the KWI said, "If you feel that you are not represented and you are confident with a clear and strong conscience that your dignity is not channelled, we can understand that you express your responsibility and freedom by not voting, and you are not sinning if you don't give your vote." ${ }^{37}$

The end of the New Order regime and era and the rise of the Reformation era that was indicated by a series of very bloody riots in several cities in May 1998 did not automatically bring Indonesia to a better condition, even just the reverse. During around six years of the so-called Reformation era the conflicts were growing worse, and they often brought serious suffering and claimed victims among the Christians. In the midst of that situation the PGI and its members together with the Evangelicals, Pentecostals, Baptists, Adventist and Roman Catholics continued to show their concern and make their contribution. Sometimes the steps they took brought controversy among the Christians and the churches as might be seen in the delivery of a 'tribute' or donation in March 1998 while Indonesia was facing the peak of the crisis. ${ }^{38}$

Through the seventh CCS in 1998 and the fourteenth general assembly at Palangkaraya (Central Kalimantan) in 2000, under the theme "Seek for God that you will live" (Amos 5:6a) and the sub-theme "Our calling to be together overcoming the crisis of the society and the nation," the PGI and its members called themselves and the whole nation to self-examination and to show a sense of crisis and of urgency. They also appealed to the other faiths, especially the Muslim community, not to be trapped by emotional behaviour or by a certain destructive design and action that would bring the nation to total construction. By observing this we turn to the following sub-section.

\section{Relationship and dialogue with people of other faith s $^{39}$}

Among the mission societies that participated in the International Missionary Conferences until 1938 there was a perception that the other faiths were objects of evangelisation (read: Christianisation). The churches in Indonesia also inherited this perception. No wonder then that in the mission era (before 1942) as well as in the period after Indonesian independence there was much

${ }^{37}$ Keprihatinan dan Harapan (Surat Gembala Prapaskah). Jakarta: KWI, 1997. Also quoted in: Aritonang 2004:515. This letter was criticised by the government.

${ }_{38}$ At that time a group of church leaders from various organisations and denominations, at the initiative of some Evangelical and Pentecostal businessmen, visited President Soeharto in his palace to submit an amount of money and gold to express the concern and responsibility of the Christians and the churches regarding the crisis then occurring. Soelarso Sopater, chairperson of the PGI in the period 1989-2000, submitted the 'tribute' on behalf of the delegates, but he denied that he did it on behalf of the PGI and that it was his initiative to make the visit.

${ }^{39}$ The content of this section is mainly based on Djaka Soetapa's article in Aritonang (ed.) 2000:165-216 and Aritonang 2004: esp. chapter IV-VI. See also chapter six of this book. 
tension caused by such a perception. This tension, especially between Islam and Christianity, was intensified by the issue of the dasar negara (the foundation of the state): Islam or Pancasila? During the Japanese and 'Old Order' or Soekarno era (1942-1965) the tension and conflict were more in formal and official forums, (BPUPKI/PPKI and the Konstituante). ${ }^{40}$ But since the beginning of the New Order or Soeharto era the tension and conflict became more openly expressed and involved common people. As already mentioned, in 1967 the Peristiwa Makassar ${ }^{41}$ broke out, and this incident was followed by many other conflicts.

Since the beginning of its existence the DGI with its members paid attention to this issue of inter-faith relationships especially with Islam. In its first (founding) conference in 1950 one of the topics discussed dealt with the Kementerian Agama (Ministry or Department of Religious Affairs). A number of participants expressed their concern that this department would lead Indonesia to become an Islamic state. In the second conference in 1953 one of the sections reported that there was a serious effort by certain Muslims to create an Islamic state where Islamic law would be applied. Based on this report, the conference issued a resolution regarding religious freedom (referring to article 18 of the Universal Declaration of Human Rights) and the Department of Religious Affairs. This second conference also arrived at a conclusion that the Christians and the churches in Indonesia were always called to proclaim the gospel to other faiths with an understanding that the core and the secret of the gospel proclamation are love for God and love for fellow humans. A similar concern was shown in the third conference in 1956; this conference arrived at a common consciousness and responsibility to see the whole country as only one evangelisation field. ${ }^{42}$

Notwithstanding certain tensions in the inter-faith encounter, especially in Christian and Muslim relations, during the Old Order era there was a common impression that the relationship between the Christians and the government was quite intimate. Soekarno put trust in a number of Christian leaders in his government (although not all of them represented Parkindo, the Christian political party), among others Dr. Johannes Leimena, Arnold Mononutu, Herling Laoh, H. Johannes, and Dr. Ferdinand L. Tobing. Leimena, an outstanding Parkindo figure, even became the second Vice-Prime Minister and was several times appointed to be acting President. Soekarno also attended

${ }^{40}$ The destruction and loss caused by the Darul Islam/Tentara Islam Indonesia (DI/TII) to a number of Christians and churches in several regions were not perceived as part of an Islam-Christianity conflict in this country, because it was caused by a separatist movement; see further in: Aritonang 2004:292-303.

${ }^{41}$ A short description of this incident is summarised in Aritonang 2004:383-388. See here chapter six.

${ }_{42}$ PGI 1996a:58-151, summarised in: Aritonang 2004:289-2891. 
and gave a speech at several important church events, such as the third and the fifth conference of the DGI in 1956 and 1964, the inaugural conference of the East Asia Christian Conference at Parapat (North Sumatra) in 1957, and in the centennial jubilee of HKBP at Tarutung (North Sumatra) in 1961. Therefore it is not surprising that the Christians (including Catholics) in 1963 endorsed a proposal to appoint Soekarno as president-for-life. ${ }^{43}$

When Soekarno's regime ended and was replaced by Soeharto's New Order, there was an expectation among certain Muslim circles that their place and role in the government would become greater. But then they were disappointed to see that so many Christian leaders were given positions of trust in the cabinets from the very beginning of that New Order regime. Even more than the various causes that triggered a number of open conflicts from 1967 on, including the bloody Peristiwa Makassar of 1 October 1967, that fact motivated certain Muslim groups and leaders to express their disappointment and also their objections to the strategies of the Christians, including the so-called Christianisation of Indonesia, soon after the abortive coup of 30 September/ 1 October 1965.

The rising tension between Christians and Muslims, caused by and following the Makassar incident, led the government to take the initiative to hold a Musyawarah Antar Umat Beragama (Inter-religious Consultation) in Jakarta on 30 November 1967, followed by a series of regional consultations in several cities such as Garut (West Java). In the 30 November consultation President Soeharto and the Minister of Religious Affairs K.H.M. Dachlan proposed a concept of 'religious harmony' that basically provided that religious propagation should not directed to people already adhering to a religion, and should not raise conflict among adherents. ${ }^{44}$ The Muslim side gladly hailed this proposal; they even provided a concept of a Joint Charter and Declaration of Islam and Christianity on Religious Harmony. The Christian side accepted most of the content of the concept except one clause, "tidak menjadikan umat yang beragama sebagai sasaran penyebaran agama masing-masing" (not to make another religion's adherents a target of the religious propagation) because they understood that this clause meant that Christian mission or evangelisation or Islamic dakwah could only be aimed to deepen their own adherents' faith. The Christians (Protestant as well as Catholic) argued that the Christian religion is a missionary religion and all mankind have a right to choose and to change their religion. ${ }^{45}$

43 See further in: Aritonang 2004:335-337 and 348-354.

44 The religions meant, and recognised by the government, are Islam, Christianity [Protestant], Catholicism, Hinduism and Buddhism. The local or tribal religions were later asked to choose and integrate themselves to one of these official religions.

45 These inter-faith consultations are summarised in: Aritonang 2004:389-393. 
Consequently this consultation failed to agree, or to produce a code of ethics of religious propagation, and the Muslim side reacted sharply to this failure. They blamed the Christian side for it, since the Christians were intolerant. But the Christian side did not accept this accusation; they agreed that improper tactics such as persuading, forcing, or giving some material aid should be prohibited, but they could not accept a situation in which they were prohibited from obeying the divine commandment to proclaim the gospel to all mankind. The tension caused by the failure of the consultation heightened when the Minister of Religious Affairs and the Minister of Internal Affairs issued the already-mentioned Joint Decision/Instruction No. 1/1969 regarding requirement for building places of worship. The failure of the consultation also brought Christian-Muslim relations into a more and more complicated situation in the future. But, on the other hand, this consultation has motivated and encouraged both sides to work more intensively to know and to understand each other. This consultation became the starting point of a series of efforts and activities in consultations and dialogue that followed on a local, regional, national and even international level.

The rising religious tension, especially the Christian-Muslim relationship in the 1960s and the need to build a dialogue occurred not only in Indonesia but also in many other countries. That is why at last, from 1970 onwards, there was a series of international dialogues initiated or sponsored by various international institutions, among others the WCC. For example, in 1970 an international religious dialogue was held in Ajaltoun (Lebanon), attended by the representatives of four religions (Christian, Muslim, Hindu and Buddhist). Mukti Ali and Peter D. Latuihamallo represented Indonesia. ${ }^{46} \mathrm{~A}$ similar conference was held by the WCC in cooperation with two study institutions from England in 1976 at Chambésy, Switzerland, attended by two Indonesian representatives, H.M. Rasjidi and Ihromi. ${ }^{47}$

There have been hundreds (not to say thousands) of interfaith consultations or dialogue forums held from the beginning of the New Order era up to the so-called Reformation era, especially between Christianity and Islam. There were also uncountable writings on this issue, irrespective of what the

${ }^{46}$ Mukti Ali, Minister of Religious Affairs, 1971-1978 and professor of Comparative Religion at State Islamic Institute Sunan Kalijaga Yogyakarta, deserves to be called "Bapak Dialogue" (father of dialogue) in Indonesia. During his ministry the inter-religious relationship, esp. Christian-Muslim, was quite encouraging. P.D. Latuihamallo at that time was chairperson of the DGI.

${ }^{47}$ H.M. Rasjidi was the first Minister of Religious Affairs (1946 onwards) in his early thirties, later he became a professor at Indonesia University-Jakarta. He was very critical of a number of government policies suspected to have been influenced by the Christians, such as the alreadymentioned draft of Marriage Law of 1973, and on certain manoeuvres of the Christians in the political field as well as in religious propaganda. Ihromi was a professor of the Old Testament at Jakarta Theological Seminary and came from a Muslim background. 
authors meant by dialogue. There were even a number of interfaith institutions founded to handle this issue. But as a matter of fact conflicts containing religious dimensions and even riots were rising, with accumulating effects. Therefore it is not surprising that some critical questions were expressed: for what purpose are all these consultations or conferences of dialogue? Is it not a waste of time, funds and energy? Are they not just a mask or camouflage to hide certain intentions and plans of the respective sides that are frequently contrary to what they were addressing in such a dialogue forum? On the other hand some activists and protagonists of dialogue replied that simply because there were still numbers of conflicts and riots we still need, and have to continue, dialogues to express our respective opinions, convictions, identities and feelings as well as to undertake self criticism and introspection. It was, however, realised that many of the dialogues were initiated and sponsored by the government and had a political agenda behind them, so that it was difficult to come to a genuine and authentic dialogue.

In such a situation and condition the DGI/PGI through its research and development department (Lembaga Penelitian dan Studi, later changed to Badan Penelitian dan Pengembangan, Balitbang), from 1981, held a series of Seminar Agama-agama (Seminars on Religions) that were essentially a forum of interfaith dialogue. Besides inviting participants and speakers from all the 'official' religions, this seminar also aimed to equip and to train students from a number of theological schools (especially members of Persetia) in interfaith knowledge and the skills of dialogue. Each seminar was held under a certain theme, such as "Review of Islam from various aspects" (1981), "The development of the Islamic movement and thinking in Indonesia" (1982), "Religion and Modernisation" (1985), "Morality and Ethics in Nation-Building" (1987), "Environment and National Development" (1988), "Spirituality in Modern Society" (1989), "Religion and Economic Development" (1991), "Pluralism and Democracy" (1992), "Religions and Cultural Challenge" (1994), "Religions towards the third millennium" (1996), and "Religions, Violence and Peace in the Reformation Era" (1999).

Closing his review of the seminars held in 1981-1999, Djaka Soetapa concludes that through these seminars it was shown that religions have the same agenda and concerns that are based on humanity and have a divine dimension. All religions have an aspiration to manage these agendas and concerns and therefore, if conflicts with religious dimension occurred then the religions deny and disappoint their own calling. ${ }^{48}$ Although this series of seminars has not yet shown its real contribution for promoting more harmony and mutual understanding the PGI and its members persist in accepting their share of

\footnotetext{
${ }^{48}$ Soetapa's review and conclusion is summarised in: Aritonang 2004:497-511.
} 
the responsibility in building and enhancing a more conducive and healthier inter-religious relationship. ${ }^{49}$

\section{Environmental concern ${ }^{50}$}

In line with WCC's concern, shown since its fourth general assembly in Uppsala 1968, and culminating in the sixth general assembly in Vancouver 1983 under the theme "Justice, Peace and the Integrity of Creation" (JPIC), DGI/PGI began to show its concern for environmental issues from 1970, through a special conference, the above-mentioned Cipayung Conference, and at its seventh general assembly at Pematangsiantar in 1971. This environmental concern was related to the development program of the government, since development frequently brought destruction to the environment. The third CCS in 1976 had already reaffirmed that science and technology had to be used for the welfare, peace, justice, and sister/brotherhood of all nations and for the conservation of nature and the environment.

This concern was intensified during 1980s as expressed in the ninth general assembly of the DGI in the 1980 and in the fourth CCS in 1984. The eighth Seminar on Religions in 1988 took the JPIC theme seriously. The PGI even held a national consultation on JPIC at Salatiga (Central Java) in 1989 as a preparation for the fifth CCS in the same year. After describing many cases of environmental destruction this fifth CCS formulated the responsibility of the churches in Indonesia among other things as follows:

The churches together with all their members and networks ought to start solemnly accepting the responsibility as humans and fellow creatures to apply the Word of God i.e. to maintain the integrity of creation, justice and peace, as their attitude of worship. This assumes that the churches together with all their components are aware of their role to obey God's covenant that is simultaneously an invitation to all human beings and creatures and to accept the reconciliation made by the Giver of Life, Jesus Christ. ${ }^{51}$

Following this statement, the CCS proposed to the PGI and its members a set program on Integrity of Creation, Justice and Peace, consisting of conscientisation, confession of the sin of destroying the environment, Bible study on this theme, formation of working groups to handle and elaborate the issues

49 For 2005 PGI plans to hold such a seminar under a theme "Theodicy and Theology of Disaster" inspired by the tsunami and earthquake disasters at the end of December 2004 and March 2005, besides some "social disasters" like those in Papua and Poso-Central Sulawesi."

50 A summary of this topic prepared by Robert P. Borrong in: Aritonang (ed.) 2000:147-54. A detailed description could be found in the minutes of various conferences and assemblies held by the DGI/PGI since 1970s.

51 Visi Baru untuk Era Baru dengan Generasi Baru-Laporan Konferensi Nasional Gereja dan Masyarakat V, PGI, 18-21 April 1989, di Wisma Kinasih, Caringin-Bogor. Jakarta: Akademi Leimena PGI, 1989:109. 
related to the theme, building of networking with any groups or institutions that have the same concern, and initiating study and action on environmental issues. This statement and programme proposal was discussed and sharpened further in PGI's twelfth general assembly at Jayapura in 1994. One of the concrete decisions of this assembly was to establish a special foundation with the main task of handling any kind of environmental destruction and disaster. The implementation of this decision was fulfilled in 1996 by establishing the Yayasan Tanggul Bencana (the Foundation to Handle Disaster). ${ }^{52}$

This environmental concern was also inserted by Persetia (the association of theological schools) into its considerations and program. In 1999 its Study Institute, in cooperation with the Badan Penelitian dan Pengembangan (Research and Development Unit) of the PGI, set up a special syllabus on environmental concerns in the curriculum, with an expectation that every graduate of a theological school will have a strong environmental awareness and attention that in turn will be applied and developed in their ministry among the people and the churches.

The PGI's thirteenth assembly at Palangkaraya in 2000 also pushed the churches and society to deepen their understanding and to enhance their action on the human rights and environmental issues. This assembly even endorsed the PGI's setting up of a special unit to handle environmental issues, namely the Badan Pemberdayaan dan Advokasi Lingkungan Hidup di Indonesia (Unit of Empowerment and Advocacy of Environment in Indonesia), while it also underlined the Persetia program of including Environmental Education in the curriculum of theological schools.

The most fundamental theological concept of the PGI and the churchmembers regarding this environmental concern is formulated in one of the Documents of Church Unity, the Pemahaman Bersama Iman Kristen, chapter II: Creation and Conservation. How far this concept and the program derived from it were implemented and brought improvement to the environment in Indonesia is still to be discussed and observed, because up to the present moment the destruction of environment and the exploitation of natural resources is still going on, and even worsens from time to time.

\section{Information, publication and communication ${ }^{53}$}

From the very beginning there was a consciousness that the growth and the progress of the ecumenical movement should be publicly and widely exposed

${ }^{52}$ This foundation, although by incident split from PGI in early 2005, was trusted by overseas partners coordinated by ACT (Action by the Churches Together) to participate in the recovery of post-tsunami disaster program in Aceh and Nias.

${ }_{53}$ On this subject see also chapters sixteen and twenty-one. 
and communicated, not only to the church and Christian circles but also to the whole nation. Therefore already in the first conference of the DGI there was a special commission to set up a plan in this regard, among other ways by using radio broadcasting and printed mass media already available. The DGI and the member churches intentionally used these media not only as agencies to give information about what they were doing but also to proclaim the gospel based on the consciousness and understanding that the whole nation and country was an open field of evangelisation.

Until early in the 1960s the publications of the DGI as well as of its members were very limited, in line with the still limited development of information and publication technology. Some of the debates in the churches were published in the form of books or booklets by Badan Penerbit Kristen, a Christian publishing house already formed in 1946 while the churches prepared the founding of a national council or chamber (see section 2). But since the mid 1960s there was remarkable progress. Some church leaders, including those who were sitting in the structure of the DGI, started a Christian newspaper called Sinar Harapan (Rays of Hope) besides continuing to use the other printed media to expose churches' and DGI's activities, programs, statements and ideas. Parallel with this they also launched a Christian-flavoured popular-science monthly, Ragi Buana (Yeast of the World) in $1967 . .^{54}$

Not long after the opening of the government TV broadcasting (TVRI) in 1962, the DGI and the churches used a programme slot every Sunday afternoon, called Mimbar Agama Kristen (Pulpit of Christian Religion). In the course of time DGI had to share it with some other denominations outside the DGI, such as Roman Catholic, Pentecostal, Adventist and Baptist. The sharing also contributed to the enhancement of cooperation among these churches. Meanwhile, in the 1970s, the DGI/PGI formed a special unit (then reconstituted as an autonomous foundation called Yayasan Komunikasi Masyarakat, or Yakoma) to prepare and manage the TV program package, not only broadcast by TVRI but also by a number of private TV stations that have flourished since the 1980s. Yakoma also provided various programs in the field of communication such as the training of TV-drama actors, writers, reporters, and the publishing of some books along with a bulletin named Komunikasi. ${ }^{55}$ Since the late 1990s the content of this bulletin and the statements of Yakoma

${ }^{54}$ This Reader's Digest-style magazine only persisted until the early 1980s, whereas the similar magazine, Intisari, from the Catholic-Gramedia-Kompas group, persists and even flourishes up to the present moment.

${ }_{55}$ More detailed information on Yakoma as well as the other foundations or working units under the umbrella of the DGI/PGI can be found in the annual report or five-year report of the DGI/PGI such as Dari Salatiga ke Tomohon (1980), Dari Tomohon ke Ambon (1984), Dari Ambon ke Surabaya (1989), Dari Surabaya ke Jayapura (1994), Dari Jayapura ke Palangkaraya (2000) and Dari Palangkaraya ke Kinasih-Caringin-Bogor (2004). 
as well, quite frequently criticized the policies and decisions of the PGI. This is only a small example from a huge and complicated complex of problems faced by the PGI since then.

Besides opening an Information Office, since the 1970s the DGI/PGI has also published its official monthly, Berita Oikoumene. Actually this was expected to be a public magazine, but since it mainly contained reports of the activities of the DGI/PGI and its members, or articles written by their leaders or thinkers for church consumption, and because it was not managed professionally, this magazine could not flourish. Occasionally, particularly during the era of external (national) and internal crisis, it got into difficulties due to financial problems and could only be re-issued after some incentives from the PGI's home or overseas supporters.

During the period of the 1970s to the 1990s the DGI/PGI also diligently published the documents of its meetings, conferences, assemblies, and the compilation of its statements regarding various themes, through BPK Gunung Mulia or through its own office. These statements, including Christmas and Easter Messages and pastoral letters on certain issues or incidents, were usually circulated by mail to all members and to many other Christian organisations. Since 1994 the PGI also used Internet facilities and provided a website to communicate faster and more efficiently. Unfortunately this website was also not handled professionally so that the users have no access to up to date news. Similar conditions can also be found regarding some other church or ecumenical communions. Fortunately there are many other Christian media or communication agencies, especially those managed by the Catholics that steadily grow and even show significant progress in terms of quantity as well as quality.

Reviewing various kinds of media and methods used by the DGI/PGI and some other church or ecumenical institutions, and seeing how diligently they formulated attractive statements, it appears likely that they should have been playing an important role in communicating Christian vision, mission and ideas to the whole nation, including a prophetic and priestly voice dealing with so many crucial issues and problems in this country. Surprisingly, or regretfully, there are still complaints that DGI/PGI as well as the other so-called ecumenical organisations could not communicate their message clearly and effectively to the people and the government. ${ }^{56}$ Some observers argued that it is actually quite normal and natural, since the percentage of Christians is very small while the current society and government are dominated by Muslim or secular ideas. Moreover PGI and other ecumenical bodies have no power to

${ }^{56}$ This sort of complaint is frequently expressed in many Christian meetings and gatherings, even those held by the DGI/PGI itself or together with some other organisations. 
make their voice or opinion and standpoint heard and followed by anyone. There must be, however, some other causes that make the existence and the role of the PGI and other ecumenical communions not very widely felt and meaningful. We will try to trace them in the following, and final, section.

\section{Some Current Problems and Struggles}

Since the 1970s there were many criticisms directed against the DGI/PGI. The presence of some other 'ecumenical' bodies among the Protestant churches (PII, DPI/PGPI, PBI and others) can also be understood as an expression of dissatisfaction with the performance of the DGI/PGI, or with its failure to embrace and unite all [Protestant] churches in this country, although on the other hand there are more and more Evangelical and Pentecostal churches who have joined this communion. ${ }^{57}$ Corresponding to this is the theological colour or tendency of the DGI/PGI. When it was founded, the DGI adopted and inherited the theology of the mission societies and their founding churches that was more or less the combination of orthodox Protestantism and Pietism-Revivalism. But then gradually the theology of the WCC that was commonly known as ecumenical, became more dominant, and in the eyes of the Evangelicals and Pentecostals this tended to liberal or horizontal-oriented. Even members of DGI/PGI-mostly traditional and regional or ethnic churches-did not easily understand and follow the new theology. That is, among other factors, the reason why the members of the DGI/PGI as well as the regional communions (PGI Wilayah) could not easily implement the decisions of the DGI/PGI, including the LDKG/DKG, although they theoretically participated and were involved in the process of decision-making.

Together with this theological problem the PGI and its members struggled with many other problems. We will only highlight some of the striking issues that especially appear in the last ten years (1995-2005).

\section{The fading and disorientation of the ecumenical spirit}

One of the sharpest criticisms thrown at the PGI is that it more and more tends to be bureaucratic and institutional. In the centralistic-formalistic structure of the PGI the ecumene lost its élan vital and spirit as a movement. It

${ }^{57}$ In 2005 there are 81 member-churches of PGI (including Gereja Kristen Timor Timur that de facto already changed its name after the independence of Timor Leste in 1999), compared to 27 at the time of its forming in 1950. Around 20 of these 81 churches can also be categorised as Evangelical and/or Pentecostal. Besides, joining the DGI/PGI certain churches, like Gereja Bethel Indonesia, also join PII and/or the DPI/PGPI. The growing number of the DGI/PGI members cannot be always be perceived as the enhancement of the ecumenical spirit among the churches, because some of the new members are the products of schism. 
was indeed realised that the unity of the church does not mean uniformity and does not necessarily lead the churches in Indonesia to be institutionally one church. It was also understood that the PGI is not a super-church above all of its member-churches. The tendency of institutionalisation, however, was quite strong especially since the 1970s. The organisation of the DGI/PGI became very big. Under the general assembly there are a central committee, an executive committee, departments and bureaus, about twenty foundations, and a number of working groups. On the one hand this caused inertia in its action and in making decisions, while on the other hand it seduced many church leaders or activists to pursue full-time positions, especially during the boom-time of overseas grants.

When the PGI celebrated its jubilee in 2000 there was a gloomy atmosphere. Besides lamenting the result of nominations (see below) there was the awareness and anxiety that not only the PGI but also the ecumenical movement as a whole was threatened and could become disoriented and fade away. To avoid this some observers gathered in a series of meetings on the revitalisation of the ecumenical movement in Indonesia, and the result was published in a book. In that meeting it was stated that the ecumenical movement in Indonesia-including the PGI-needed re-evaluation, redefinition, revitalisation, reorientation and reformation. ${ }^{58}$ Corresponding to this $5 \mathrm{R}$, it was stated that:

The problem that particularly needs to get attention in this $5 \mathrm{R}$ movement is a paradigm change from an exclusive ecumenical movement to an inclusive ecumenical movement; from an inward-looking ecumenical movement to an outward-looking ecumenical movement. The fifty years journey of the ecumenical movement in Indonesia, especially motored by PGI, tends to be exclusive and narrowing, it only viewed a unity of church organisation, which is in fact not achieved yet. An outward movement, to the society (outward looking), is still getting very minimal attention and therefore the ecumenical movement became weak..$^{59}$

To recover the ecumenical spirit and orientation, while entering the twenty first century, the meeting recommended some agenda issues, among others to redefine the vision and mission of the PGI, to leave the centralistic approach and to develop the principle of decentralization and regional autonomy, and to plan a systematic cadre-forming through the so-called ecumene-education.

\section{The crisis of leadership and trust}

In spite of many shortcomings and the weakness of the ecumenical movement in general and the DGI/PGI in particular, during the almost forty years of its presence the DGI/PGI has had quite strong leaders and leadership. Some leaders like T.S. Gunung Mulia, Simon Marantika, W.J. Rumambi, J.L.Ch.

58 Robert P. Borrong and Supardan (eds) 2001:17-20.

59 Robert P. Borrong and Supardan (eds) 2001:18. 
Abineno, P.D. Latuihamallo, T.B. Simatupang, S.A.E. Nababan and Fridolin Ukur were well-known persons with integrity. They were also successful in building a networking with and trust from many circles. Sularso Sopater was actually a good, very fatherly leader and a man with integrity, although he was incidentally trapped in the case of the "tribute to the palace." With their leadership at least the Christians and the church-members of the DGI/PGI have boldness and self-esteem when they were facing serious problems or pressure regarding the existence of the Christians in this country.

But during the period of 2000-2004/5 the PGI faced a serious crisis of leadership and trust, and this had a close connection with the result of nominations in the thirteenth general assembly at Palangkaraya in 2000. At this assembly, through an abnormal (not to say amoral) process of nomination Natan Setiabudi was elected as the general chairperson. This aroused a protest from a number of church leaders and activists that was expressed in a press release.$^{60}$ In the press release it was stated that the process and result of the nomination jeopardized the future of the ecumenical movement in general and the PGI in particular, and was also contrary to the spirit of reformation that was blossoming in this country.

In fact Natan Setiabudi held the position although his term together with the other executive committee members had to be a little shortened through an accelerated general assembly in December 2004 (instead of March 2005). During his leadership there were many problems, among others: he could not properly cooperate with the general secretary, Ishak Panumbu Lambe. Their conflict and disagreement had actually started a few years before but then sharpened during their term as the two key persons in the PGI. Also, many member-churches that did not elect Natan also did not support him or have trust in him.

This non-conducive situation in turn brought the PGI as well as the ecumenical atmosphere and performance to its nadir. The PGI could not set up its operational program and could not give a verifiable financial report, including the use of funds from partners. Eukumindo, an ecumenical body in Europe that has gathered and represented PGI's church-partners in Europe from the 1970s, no longer put trust in the PGI and blocked the designated funds. As a matter of fact this unaccountability had already been shown by the PGI for a long time, especially since the early 1990s, and this was the main cause of the

${ }_{60}$ "Press Release Pernyataan Keprihatinan Komunitas untuk Reformasi Gereja mengenai Situasi Persekutuan Gereja-gereja di Indonesia (PGI) dan majelis Pekerja Harian (MPH) saat ini," 27 April 2000. This document was, among others, signed by S.A.E. Nababan, Eka Darmaputera, Septemmy Lakawa (see chapter sixteen), Febry Tetelepta (a young leader) and Luhut M.P. Pangaribuan (a famous lawyer). It was accompanied by a note written by Febry Tetelepta, "Catatan tentang Politisasi Kinerja Panitia Nominasi dalam Sidang Raya XIII PGI, 24-32 Maret 2000, di Palangkaraya." (n.d.). 
dismissal of the Departemen Partisipasi dalam Pembangunan (Department of Participation in the Development, Depparpem), a department in the PGI that made use of a large amount of money to finance a number of development projects ran by the PGI and its members. In all events this case of internal conflict and distrust in the period 2000-2004 sank the PGI into even deeper mire.

The Christians and churches in and outside the PGI have a big expectation that the result of the general assembly in December 2004, including the nomination and election of the new executive committee, with Andreas A. Yewangoe as the general chairperson and Richard M. Daulay as the general secretary, can recover strong leadership, trust and accountability. Time and history will be the witnesses of their success or failure. This, however, does not only depend on their strong cooperation and leadership, but also on the commitment of the churches together to continue and to enhance the quality of the ecumenical movement.

\section{The financial dependency on foreign/international partners}

In line with its growth and widening task to promote the ecumenical movement and spirit, the DGI/PGI needed greater and greater funds. An appeal was made to the members to contribute an annual membership fee, but this amounts to almost nothing compared to the mounting budget, even if all members paid duly and fully. There are, of course, a number of dedicated home supporters-businessmen and the like-who have donated to the DGI/PGI or to other ecumenical bodies, but usually they give it incidentally so that those bodies cannot rely upon them for their regular budget. Regarding the approximately twenty foundations under the umbrella of the PGI, there are a few that are already financially self-reliant, like the Yayasan Rumah Sakit PGI Cikini (Cikini PGI Hospital Foundation). Some foundations are autonomous and raise their own funds, including funds from overseas resources; examples are Yakoma and Yayasan Tanggul Bencana. There are even some foundations, like the Yayasan Oikoumene, that were particularly founded to manage the endowment funds (formerly granted by some overseas partners) or to manage a number of properties (like the guesthouse in Jakarta and the conference resort in Cipayung) that in turn provide some amount of funding to back up the program and regular expenses of the PGI. From time to time, however, especially in this last ten years, the PGI had to rely upon the support or donations of its overseas partners to finance its program. Meanwhile the PGI's financial condition and reports showed a serious deficit that also needs overseas help to cover. ${ }^{61}$

${ }^{61}$ See PGI's financial reports at the thirteenth and fourteenth assemblies in 2000 and 2004, as 
As already noted, one of the causes of the deficit was the financial unaccountability and mismanagement, not to say fraud by certain personnel. During these last years there was also a consciousness that the PGI has to go back to basics, that is to foster and to preserve the spirit and fire of the ecumenical movement, and not to act too much as a sort of holding company. In line with a new Undang-undang Yayasan (Law on Foundations), gradual steps are being taken to reduce the number of foundations that have no direct link with the 'core business' of the PGI, or that have potential to maintain their existence and task independently of the PGI. Parallel with this, soon after the fourteenth general assembly of 2004 the PGI held a management and organisational assessment and capacity-building training to improve its performance and capacity. ${ }^{62}$ With these steps it is expected that in the future the PGI can show a better accountability and credibility and also become more financially self-reliant.

\section{Relationship and interaction with the government and political powers}

As repeatedly shown, from the very beginning implementation of the ecumenical movement and spirit, especially as carried out by the DGI/PGI, frequently had to do with the government. This is one of the consequences of taking over the task of the Zendingsconsulaat, as well as the policy of the government, at least until the middle of the New Order Era, that the DGI/PGI represented the Protestants in dealing with the government. That was the reason why during the Old Order and until the middle of the New Order era one person from the DGI/PGI (usually the chairperson) became a member of the Majelis Permusyawaratan Rakyat (MPR, People's Assembly).

There was no single picture of this relationship. Not infrequently the relationship was very close and warm (we remember Soekarno). Even during the New Order era that was marked by so many incidents and conflicts, at least until the late 1980s the relationship was quite friendly. There were almost no large ecumenical and church events that were not attended by government officers, who were also asked to give a speech or address. This habit or custom also occurred-and not infrequently in more striking form-in the Evangelical and Pentecostal circles. But as we have already seen there were also many cases that showed a high level of tension or even conflict between the DGI/PGI and/or its members and the government. The HKBP case in 1992-1998 is one of the very striking examples, besides those involving the GKI Papua and the GKST Central Sulawesi around 1998-2004.

well as at the annual reports in the annual meeting of Sidang Majelis Pekerja Lengkap (Central Working Committee Meeting).

${ }_{62}$ Therefore in February 2005 PGI-helped by WCC and CCA-invited Leo Basyham (a management consultant hired by WCC) and Tony Waworuntu (one of the associate secretaries in CCA). 
For financial needs the DGI/PGI, like many churches and Christian organisations, also frequently asked for government contributions or donations; if not from the government institution itself support was expected from the officials, especially those who were Christian. ${ }^{63}$ This habit made it difficult for the PGI and the leaders of member churches to show and maintain a critical standpoint. As for Simatupang's "tetra-words" i.e. positive, creative, realistic and critical, the last word was frequently neglected. For the future it is still a big question whether the PGI and all ecumenical bodies, together with the churches in this country, have a boldness and toughness sufficient to keep a distance from those holding power, without becoming 'rebel priests', or continuing to rely upon the protection and backup of the government, while the government tends to be more Islamic. It is, of course, possible that by building a close relationship with the government the churches and the ecumenical bodies are also building a more harmonious relationship with the other faiths, especially Islam. But many examples from the history of this country show that the Islamic members of the government were not always from the moderate and inclusive line.

Jan S. Aritonang

\section{Bibliography}

Aritonang, Jan S. et al.

1996 Tahun Yobel Itu Haruslah Kudus Bagimu!-50 Tahun BPK Gunung Mulia. Jakarta: BPK Gunung Mulia.

Banawiratma SJ, J.B. et al.

1994 Tempat dan Arah Gerakan Oikumenis. Jakarta: BPK Gunung Mulia.

Erari, Karel $\mathrm{Ph}$.

1994 Supaya Engkau Membuka Belenggu Kemiskinan-Dewan Gereja-gereja di Indonesia dalam Trend Perkembangan Gerakan Oikoumene dan Partisipasi Gereja dalam Pembangunan Bangsa selama Dasawarsa Enampuluhan-Tujuhpuluhan. Jakarta: BPK Gunung Mulia.

Hartono, Chris

1984 Gerakan Ekumenis di Indonesia. Yogyakarta PPIP Duta Wacana.

Hoekema, A.G.

1997 Berpikir dalam Keseimbangan yang Dinamis (transl.). Jakarta: BPK Gunung Mulia.

Holtrop, P.N.

1982 Selaku Perintis Jalan Keesaan Gerejani di Indonesia. Ujung Pandang: ISGIT.

Jonge, Chr. de

1990 Menuju Keesaan Gereja. Jakarta: BPK Gunung Mulia.

${ }^{63}$ The most recent examples are donations for the thirteenth general assembly (a large amount was donated by a president director of a government bank) and for the renovation of the PGI's office in Salemba Raya 10 Jakarta (from some retired generals who are still active informally in the government). 
Jongeling, M.C.

1966 Het Zendingsconsulaat, Arnhem: Van Loghum Slaterus.

Leirissa, R.Z. (ed.)

1980 Kewarganegaraan yang bertanggungjawab. Mengenang Dr. J. Leimena. Jakarta: BPK Gunung Mulia.

Lumentut, Agustina

1999 "Mau ke Mana Gerakan Keesaan di Indonesia?," in: Ferdinand Suleeman et al. (eds.), Bergumul dalam Pengharapan-Struggling in Hope. Jakarta: BPK Gunung Mulia.

Nababan, S.A.E. (ed.)

1968 Panggilan Kristen dalam Pembaruan Masjarakat-Laporan Konperensi Nasional Geredja dan Masjarakat 19-29 Djuni 1967. Djakarta: BPK Gunung Mulia.

Ngelow, Zakaria

1982 Jalan Keesaan DGI. Jakarta: SEAGST (M.Theol. thesis).

1994 Kekristenan dan Nasionalisme. Jakarta: BPK Gunung Mulia.

1996 "Sejarah Singkat Gerakan Keesaan Gereja di Indonesia", in: Henky C. Wijaya et alii (eds.), Jalan Menuju Keesaan. pp. 47-50. Jakarta: Pustaka Sinar Harapan.

Pattiasina, J.M. et al. (eds.)

1990 Gerakan Oikoumene Tegar Mekar di Bumi Pancasila. Jakarta: BPK Gunung Mulia.

PGI

1996a Jejak Langkah Gerakan Oikoumene di Indonesia-Dokumen Historis Pembentukan DGI dan Sidang Lengkap DGI I-III (1950-1956). Jakarta: Sekretariat Umum PGI.

1996b Arak-arakan Oikoumene Meniti Tahun-tahun Pertumbuhan-Dokumen Historis Sidang Lengkap IV DGI 1960-Sidang Lengkap V DGI 1964. Jakarta: Sekretariat Umum PGI.

1996c Lima Dokumen Keesaan Gereja, Persekutuan Gereja-gereja di Indonesia-Keputusan Sidang Raya XII PGI Jayapura, 21-30 Oktober 1994. Jakarta: BPK Gunung Mulia.

2001 Dokumen Keesaan Gereja 2000-2005. Jakarta: PGI.

2005 Dokumen Keesaan Gereja 2004-2009. Jakarta: PGI.

Sairin, Weinata (ed.)

1994 Himpunan Peraturan di Bidang Keagamaan. Jakarta: BPK Gunung Mulia.

1998 Pemilu, GBHN, dan Visi Sosial Kemasyarakatan-Perspektif Gereja-gereja di Indonesia. Jakarta: BPK Gunung Mulia.

Sairin, Weinata and J.M. Pattiasina (eds.)

1994 Pelaksanaan Undang-undang Perkawinan dalam Perspektif Kristen. Jakarta: BPK Gunung Mulia.

Sidjabat, W.B.

1964 Panggilan Kita di Indonesia Dewasa Ini. Djakarta: BPK Gunung Mulia.

1968 Partisipasi Kristen dalam Nation Building di Indonesia. Djakarta: BPK Gunung Mulia. Simatupang, T.B.

1968 "Partisipasi Kristen dalam Revolusi di Bidang Politik," in: W.B. Sidjabat (ed.), Partisipasi Kristen dalam Nation Building di Indonesi. pp. 7-35. Djakarta: BP.

1987 Pembangunan Nasional sebagai Pengamalan Pancasila: dari buntut dalam GBHN 1983 menjadi jantung dalam GBHN 1988. Jakarta: UKI.

Ukur, F. et alii

1979 Jerih dan Juang-Laporan Nasional Survai Menyeluruh Gereja di Indonesia. Jakarta:

Verkuyl, J. LPS DGI.

1961 Geredja dan Bidat ${ }^{2}$ (Church and Heresies), Djakarta: BPK Gunung Mulia.

Wijaya, Henky et alii (eds.)

1996 Jalan Menuju Keesaan. Jakarta: Pustaka Sinar Harapan. 